\title{
8. FORAMINIFER BIOSTRATIGRAPHY, NORTH PHILIPPINE SEA, DEEP SEA DRILLING PROJECT LEG 58
}

\author{
Dorothy J. Echols, Department of Earth and Planetary Sciences, Washington University, St. Louis, Missouri
}

\begin{abstract}
During Leg 58, part of the DSDP program of drilling on active ocean margins, five sites were drilled in the north part of the Philippine Sea - three in the central part of the Shikoku Basin, and two to the southwest, in the Daito Ridge and Basin province.

Samples from the Shikoku Basin sites $(442,443,444)$ represent Quaternary through middle-Miocene sediments. In this basin, water depths are believed to exceed the carbonate-compensation depth (CCD), for no carbonate organisms have been found in the surface sediments. Both planktonic and benthic foraminifers were very rare and poorly preserved in these samples, indicating that the depth of deposition fluctuated near the CCD. The few identified key planktonic species show general agreement with the nannofossil and radiolarian biostratigraphy. The autochthonous benthic assemblages at all three sites are characteristic of deep water.

Samples from the two sites $(445,446)$ in the Daito Ridge and Basin province represent Quaternary through early-Eocene sediments. The autochthonous foraminifers of Site 445 are, over certain intervals, suitable for biostratigraphic and environmental study. Some foraminifer zones are recognized at Site 446. Although deposition at Site 445 is believed to have been above the CCD, foraminifers are rare or absent in certain intervals. At Site 446, the foraminifers indicate that the depth of deposition fluctuated near the CCD. At both sites, thick sequences of resedimented sandstones, siltstones, and mudstones in turbidites occur in the early and middle Eocene. In these sediments, abundant shallow-water larger and smaller benthic foraminifers were recovered in varying states of preservation. It is suspected that these deposits were derived from ridges fairly close to the depositional basin.
\end{abstract}

\section{SHIKOKU BASIN}

\section{Introduction}

Three sites $(442,443,444)$ were drilled in the Shikoku Basin in the north Philippine Sea (Figure 1).

Primary objectives of drilling in the Shikoku Basin were to study the geological history and to test the validity of sea-floor-spreading models. The paleontological objectives were to determine basement ages, which might in turn indicate the age and kind of spreading; to infer paleocirculation and paleoenvironment; and, where possible, to establish biostratigraphic zonation (Table 1).

The time scale used in the foraminifer biostratigraphy is adapted from Berggren and Van Couvering (1974), Saito (1977), van Andel et al. (1975), and Hardenbol and Berggren (1978). The preliminary Neogene and Paleogene planktonic-foraminifer zonations include those established by Bolli $(1957,1970)$, Banner and Blow (1965), Blow (1969), Jenkins (1966, 1967, 1971), Brönnimann and Resig (1971), Postuma (1971), Jenkins and Orr (1972), Kennett (1973, 1975), Vincent (1975), Stainforth et al. (1975), and Saito (1977).

\section{Site $\mathbf{4 4 2}$}

The summary of Holes 442, 442A, and 442B is based on all samples collected aboard ship. Foraminifers were rare and at best only moderately well preserved, indicating proximity of the depositional surface to the CCD. In no case were more than a few specimens (2026) found on a tray; therefore, it is meaningless to establish relative abundances. A detailed tabulation of foraminifers recovered at Site 442, is found in Appendix 1.

Sediments drilled in the Shikoku Basin span the Holocene through the middle or early Miocene. Foraminifer recovery was disappointing, but this was expected. As mentioned previously, the basin is now below the CCD, and it was anticipated that this situation might well prove to have been the case in the geological past. However, in a few instances rare key planktonic foraminifers were recognized that indicated ages in general agreement with the nannofossil and radiolarian determinations (Okada, this volume; Sloan, this volume). For example, in Core 442B-2, the few fragmented and partially dissolved forms related to the Sphaeroidinella group might be significant. At first it was believed 


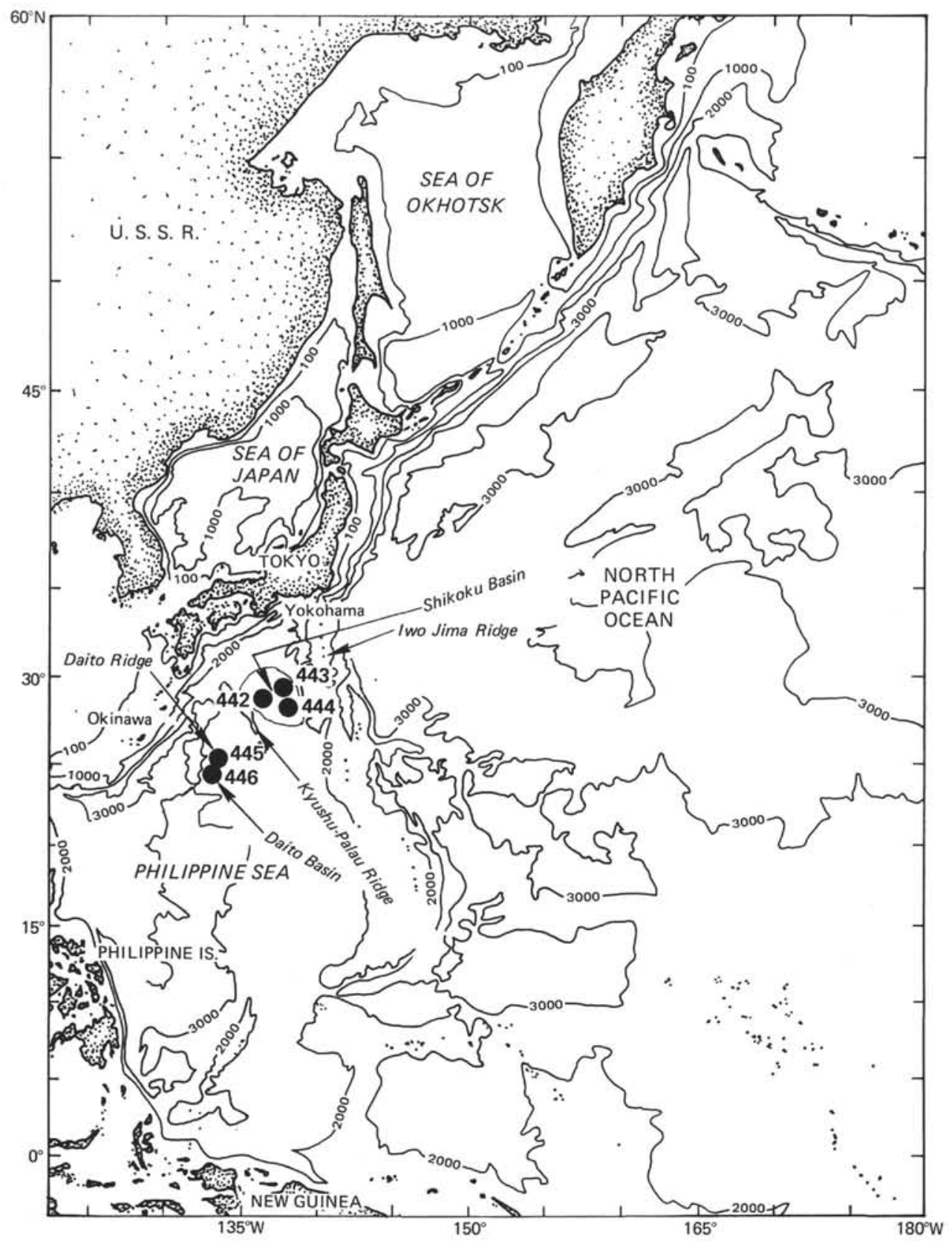

Figure 1. Location of DSDP Leg 58 sites.

that these forms were $S$. subdehiscens with the cortex removed by dissolution. However, under higher magnification it appears that they are more closely related to Prosphaeroidinella Ujiie, 1976. In establishing the new genus Prosphaeroidinella (type species $P$. disjuncta), Ujiie indicated that this species is "bilamellar"; as new chambers are added, secondary thickening of the wall is due to outward growth of calcite crystals and a smooth outer (surface) cortex layer is not formed. Prosphaeroidinella is considered the direct ancestor of Sphaeroidinellopsis and has a geologic range of 18 to $13 \mathrm{Ma}$.

It is of interest that Cores $442 \mathrm{~A}-13$ through $442 \mathrm{~A}-20$ are barren of foraminifers. Nannofossils are also absent from this section suggesting that the depositional surface was well below the CCD during this interval.
However, in Core 442A-21 there is an occurrence of completely replaced casts of (benthic?) foraminifers. These become common to abundant in Cores 442A-22 through 442A-24, and few to rare in Cores 442A-25 through 442A-28. Nannofossils reappear in Section $442 \mathrm{~A}-26-2$. The replacement mineral, as determined by $\mathrm{X}$-ray diffraction and atomic absorption, is rhodochrosite $\left(\mathrm{MnCO}_{3}\right)$ (Echols et al., this volume). If these foraminifers were replaced in situ, one might assume that deposition was somewhat above the $\mathrm{CCD}$ at that time.

\section{Site $\mathbf{4 4 3}$}

At this site one hole was drilled, which penetrated 457 meters of sediment (Holocene through middle Miocene) before basalt was encountered. All of the samples allot- 
TABLE 1

Foraminifer Zones Used in this Report and Approximate Ages of Their Bases

\begin{tabular}{lc|ll}
\hline Zone & $\begin{array}{c}\text { Age of Base } \\
(\mathrm{m} . \mathrm{y} .)\end{array}$ & Zone & $\begin{array}{c}\text { Age of Base } \\
(\mathrm{m} . \mathrm{y} .)\end{array}$ \\
\hline N.23 & .7 & N.5 & 20.5 \\
N.22 & 1.6 & N.4 & 22.5 \\
N.21 & $\sim 3$ & P.22/N.3 & $25.5-26$ \\
N.19 & 4.8 & P.21/N.2 & $28-30$ \\
N.18 & 5.1 & P.20/N.1 & 35 \\
N.17 & 7.7 & P.20/P.19 & 35 \\
N.16 & 10 & P.18 & 37.5 \\
N.15 & 10.3 & P.17 & 39 \\
N.14 & 11.2 & P.16 & 41 \\
N.13 & 12 & P.15 & 43 \\
N.12 & 12.4 & P.14 & 44.5 \\
N.11 & 13.9 & P.13 & 45.5 \\
N.10 & 15.3 & P.12 & 46.6 \\
N.9 & 16.0 & P.11 & 48 \\
N.8 & 17.2 & P.10 & 49 \\
N.7 & 17.3 & P.9 & 50 \\
N.6 & 18.6 & P.8 & 51 \\
\hline
\end{tabular}

ted to the foraminifer study were processed for this report. The foraminifers were sparse, and the preservation poor. Occurrences are tabulated in Appendix 2.

From Appendix 2, it is apparent that the foraminifer assemblages are poor. All samples are fragmented and show dissolution. Deposition must have taken place very close to and below the foraminifer solution depth.

Core 443-12 may be close to the Pleistocene/Pliocene boundary (approximately $1.6 \mathrm{~m}$.y.). Cores $443-14$ through 443-47 are essentially barren. In Core 443-48, a sparse and poorly preserved assemblage may indicate correlation with Cores 442B-2 and 444A-23. There is no evidence of the replaced casts seen at Site 442 .

\section{Site 444}

Quaternary through middle or early Miocene sediments were cored in Holes 444 and 444A. Recognizable planktonic foraminifers recovered from the Pleistocene were rare and poorly preserved. As at Sites 442 and 443, planktonic foraminifers were absent through most of the Pliocene and Miocene.

A deep-water, agglutinated benthic fauna, not seen at the previous sites, was recovered from Cores $444-9$ and 444-10. Deposition must have been below the calcareous-foraminifer solution depth.

Hole 444A was washed down to 82 meters, and coring began at that depth. A few tiny Globigerina and Globigerinita were recovered from the first core. Cores 444A-2 through 444A-22 were barren of planktonic foraminifers, with a meager and spotty distribution of benthic forms. However, in smear slides and in the fraction of material which passed through the $63-\mu$ screen, many juveniles and "microforaminifers" were observed in scattered samples.

Forms classified as juveniles are those tiny benthic or planktonic forms that have no more than a proloculus and a few chambers, whereas the "microforaminifers," although minute, are sufficiently well developed to bear adult characteristics and may be identified to genus. It has been suggested that the latter forms may represent one of the successive megalospheric generations (Echols and Schaeffer, 1960). If so, preservation of these forms may prove to be of environmental significance.

In Core 444A-23, a meager planktonic and deepwater benthic fauna occurs in a dark-reddish pelagic clay. The fauna is silicified, but the planktonic forms are so fragile and crushed that few whole specimens were recovered. Identification is therefore questionable, but the sample does seem to be correlative with 443-48, $\mathrm{CC}$ and similar to the sample from Section 442B-2-1. If the planktonic forms found in these three samples belong to Prosphaeroidinella Ujiie, 1976, a direct ancestor to Sphaeroidinellopsis, an age of late early to early middle Miocene (14-15 m.y.) is possible.

The studied samples and recovered foraminifers are tabulated in Appendix 3.

\section{Summary}

Foraminifers in samples of sediment recovered from the Shikoku Basin are rare and poorly preserved. For the three sites drilled, the only assemblages that could be identified with any degree of confidence were in the Pleistocene (N.23, N.22), and even here the fauna is meager and shows much dissolution. Only the most heavily calcified, robust planktonic forms have survived solution. The samples are therefore biased and not truly representative. No age-determinate forms were encountered from the Pliocene to the middle Miocene. At 14 to 15 m.y. a tentative correlation of the three sites and a very speculative date is suggested. This correlation is, of course, questionable because at all three sites the faunas on which it is based are poorly preserved and distorted.

At Site 442, the barren sequence through the Miocene is interrupted by the occurrence of replaced casts of what appear to be foraminifers. This must be a local phenomenon, because they were not observed in correlative sediments at the other sites. Their presence is not easily explained if at the time of deposition the area was below the CCD, which has been concluded because of the total absence of calcareous foraminifers and nannofossils.

The benthic fauna, although also sporadic, indicates deep water. Marked reworking and displaced shallowwater assemblages were not seen at the sites in this basin.

\section{DAITO RIDGE AND BASIN PROVINCE}

\section{Introduction}

The Daito Ridge and Basin province is in the northwest Philippine Sea, west of the Kyushu-Palau Ridge and east of the Ryukyu Trench. Two sites, 445 and 446 (Figure 1), were drilled in this area. This province has a complex topography of deeper-water basins and shallower ridges, which, according to Mizuno et al. (1975), Karig (1975, and Shiki et al. (1974), are remnant arcs.

East of the Daito Ridge, Site 445 was drilled in a small, shallow, elongate basin, bordered by ridges with relative heights of 1,000 to 2,000 meters. Site 446 was 
drilled in a deep basin imediately south of the Daito Ridge and north of the Oki-Daito Ridge.

The paleontological objectives at these two sites were (1) to determine the subsidence history of the Daito Ridge and the Daito Basin, (2) to establish the biostratigraphic framework of the region, and (3) to determine the age of the oldest sediment and of basement, if reached. From paleontological, paleomagnetic, and sedimentological studies, climatic changes, due perhaps to northward plate drift over the past $47 \mathrm{~m}$.y., should be detected. The paleocirculation of the Kuroshio Current should also be revealed by these studies.

\section{Site $\mathbf{4 4 5}$}

Sediments of Quaternary to middle-Eocene age were recovered at this site. The hole was drilled in a water depth of 3377 meters, which is well above the present CCD. From the abundance and preservation of the calcareous microfossils, especially the nannofossils, this seems to have been the situation throughout the time represented by the penetrated section.

The foraminifer sequence from Neogene (N.23) through Paleogene (P.11 or P.10; middle Eocene) is continuous and suitable for biostratigraphic and environmental study. However, in the short time allotted for this study, it was impossible to study the section in the detail necessary for fine biostratigraphy and absolute chronology. This report therefore presents as much information as could be gleaned from the samples that have been picked and identified.

One of the time-consuming difficulties encountered in processing samples was the induration of the Miocene through Eocene rocks. Only core-catcher samples were used for shipboard study, and even these, soaked for hours in "Quaternary O," had to be reworked on shore. For the shore-based study, all the samples were processed in a modified Campbell sample washer and disaggregated 6 to 14 hours.

A complete list of the samples processed for foraminifers, with a key to the abundance, preservation, and content of the fauna, is presented in Appendix 4. This represents a cursory examination of all samples and is subject to some error; it will of course be reevaluated as work progresses. Some of the preservation determinations may be biased as a result of the violent washing technique.

Detailed studies are now being conducted on the Pleistocene/Pliocene (with Payne) and Pliocene/Miocene (with Knapp and Lippincott) boundaries, and on the microforaminifers of the middle Miocene through Oligocene (with Ringer). It is apparent at this stage that samples at least to the middle Pliocene contain a good foraminifer fauna with good to moderately good preservation. It seems possible that we will be able to recognize significant planktonic-foraminifer events and climate fluctuations.

In general, foraminifers are abundant in the Pleistocene and Pliocene sections. In the early Pliocene, and especially from the Miocene downward, there is a marked decrease in size and diversity of the fora- minifers. Although deposition is thought to have been above the CCD throughout the time represented by the sediments cored at this site, over some intervals foraminifers are rare or absent, and in some sections they are represented only by juveniles and microforaminifers. Fluctuating climate may have influenced the faunas, and it is hoped that work in progress on these samples will provide clues for interpreting environmental conditions.

It is not now possible to include a detailed range chart of species and their abundances, but a preliminary biostratigraphic zonation based on a few significant forms has been prepared (Table 2). This chart shows the cores and dated intervals that could be used with some confidence. In general the zonation shows fairly good agreement with those based on nannofossils and radiolarians. Table 3 shows ranges of selected taxa which might be used for zonation in the Daito Ridge and Basin area. Many of these forms have been seen; others are suspected. This compilation is of course subject to considerable modification, but for the present it serves as a convenient frame of reference.

Turbidite deposits are characteristic of the Oligocene through Eocene sequences. In these sediments, shallowwater larger foraminifers, fragments of echinoids, mollusks, and bryozoans are common. The Miocene of Sample 445-35-2, 35-37 cm may represent turbidite reworking and deposition; this sample has a varied benthic fauna, including shallow- and deep-water forms and what appear to be late-Eocene planktonic forms.

In Cores 445-52 and 445-53, the shallow-water "larger" foraminifer Nummulites was recovered from a green fragmented sandstone turbidite. Core 445-53 also contained the very-shallow-water genera Baculogypsina (Miocene-Recent), Gypsina (Eocene-Recent), Sphaerogypsina (Eocene-Recent), Rupertina (Eocene?, Miocene-Recent), Asterocyclina (m. Eocene-u. Eocene), and Linderina (Eocene-Miocene). Eocene planktonic forms were also identified in this core.

The washed residue of Sample 445-57, CC is an ash, but it contains many planktonic foraminifers (possibly late Oligocene to early Eocene) that are encrusted with ash. The ash is not only stuck to the tests, but also seems to be embedded in the apertural and sutural areas. This of course could be a post-depositional phenomenon, but it does look as though the ash fell on the plankton while they were alive and the plankton came down in the water column with the ash. Under ordinary magnifications, specific identification is almost impossible; SEM photographs may shed some light on this.

Both megalospheric and microspheric generations of Nummulites occur in abundance in many of the Eocene cores from 445-60 downward. Thin sections of some of the recovered forms show them to be related to the species $N$. boninensis Hanzawa, recognized by Mizuno and Konda (1977) in dredge hauls near Daito and OkiDaito Islands. The fauna is undoubtedly reworked; however, the condition of the tests seems to indicate a short distance of transport, suggesting that Site 445 is close to the source. 
TABLE 2

Preliminary Biostratigraphic Zonation for Hole 445, Based on Selected Foraminifer Taxa

\begin{tabular}{|c|c|c|c|c|}
\hline Cores & $\begin{array}{c}\text { Age } \\
(\mathrm{m} . \mathrm{y} .)\end{array}$ & $\begin{array}{l}\text { Depth of Base } \\
\text { of Core Below } \\
\text { Sea Floor } \\
\text { (m) }\end{array}$ & Zone & Selected Taxa \\
\hline 1,2 & & 18 & N.23 & \\
\hline 5,6 & $1.6-1.95$ & 56 & N.22 & $\begin{array}{l}\text { G. truncatulinoides } \\
\text { S. dehiscens }\end{array}$ \\
\hline 7,8 & 2.5 & 75 & $\mathrm{~N} .21$ & $\begin{array}{l}\text { G. humerosa, G. obliquus } \\
\text { extremus, G. multicamerata, } \\
\text { G. praehirsuta, G. tosaensis, } \\
\text { G. dutertrei }\end{array}$ \\
\hline $10-12$ & $3-3.5$ & 113 & N.21 & $\begin{array}{l}\text { G. inflata, G. altispira } \\
\text { S. paenedehiscens }\end{array}$ \\
\hline 14 & $4+(?)$ & 132 & N.19 & $\begin{array}{l}\text { G. margaritae, S. seminulina, } \\
\text { G. crassaformis }\end{array}$ \\
\hline 15,16 & 5 & 151 & N.18 & G. tumida \\
\hline 19 & $5.5-6.5(?)$ & 179.5 & N.17 & G. dehiscens, G. bononiensis \\
\hline 21 & $\sim 6.2$ & 198.5 & N.17 & $\begin{array}{l}\text { G. nepenthes, G. plesiotumida, } \\
\text { G. ruber }\end{array}$ \\
\hline 25 & $8.5-10(?)$ & 236.5 & N.16 (?) & G. acostaensis \\
\hline 30 & 16 & 284 & N.9 & Orbulina, G. insueta \\
\hline 49 & $\sim 26(?)$ & 464.5 & P. $22 / \mathrm{N} .3$ & G. opima (S1) \\
\hline 53 & $30(?)$ & 502.5 & P. $21 / \mathrm{N} .2$ & G. ampliapertura \\
\hline 56 & & 531 & P. $20 / \mathrm{N} .1$ & \\
\hline 57 & $35-37(?)$ & 540.5 & P.18/P.17 & G. increbescens \\
\hline 72 & 44.5 & 683 & P.14 & \\
\hline 73 & & 692.5 & & G. broedermanni \\
\hline 75 & & 711.5 & P.13 & G. spinulosa \\
\hline 76 & & 721 & & ? G. index \\
\hline 77 & & 730.5 & & G. bullbrooki \\
\hline 79 & & 749.5 & P.13/P.12 & T. topilensis, G. senni \\
\hline 80 & 48 & 759 & P.11 & G. bullbrooki, G. quetra \\
\hline 85 & $48-50(?)$ & 806.5 & P.10 & G. frontosa \\
\hline
\end{tabular}

\section{Site 446}

Site 446 is in the Daito Basin immediately south of the Daito Ridge and north of the Oki-Daito Ridge (Figure 1). Pliocene through early Eocene sediments were cored. Water depth at the site is $\mathbf{4 9 5 2}$ meters, well below the present CCD. This site was below the CCD during most of the depositional history, as evidenced by the sporadic occurrence and poor preservation of the calcareous fossils, especially the foraminifers (Appendix 5).

Based on the foraminifers, the Core $446-1$ at 1.5 meters below the sea floor is Pliocene. The absence of a Pleistocene calcareous fauna is attributed to deposition below the CCD. In Core 446-2 at 11 meters the planktonic forms indicate an early-Pliocene (N.18/N.19) age. Preservation is moderately good, and the diverse benthic forms suggest a deep upper bathyal environment. During this time, deposition may have been close to, but slightly above, the CCD. In Cores 446-3 and 446-4, from 11 to 30 meters, severe dissolution is obvious again. The fauna is very poor, but appears to be Miocene. Cores $446-5$ to $446-14$ are barren of calcareous fossils, suggesting deposition below the CCD. Section 446-14-5 contains an abundant planktonic fauna, and a fair number of deep-water benthic forms. Although preservation is only moderately good to poor, the age can be determined as Oligocene, upper P.20/N.1 Globigerina ampliapertura Zone. Section 446-15-1 contains a fauna of large, arenaceous benthic lituolids, but only a few calcareous fragments, possibly contaminants from above. From here to $446-20, C C$ at 182 meters, the section is barren of foraminifers. Here the first resedimented benthic Nummulites and other large, shallowwater calcareous forms were recovered from a coarsegrained, resedimented clastic sediment. In Cores 446-23 and 446-25, middle-Eocene planktonic forms occur in green sandstone and mudstone turbidites with abundant shallow-water benthic forms. In Core 446-30, the planktonic forms are early middle Eocene, and the biogenic pelagic ooze encountered in Section 446-34-4 seems to be late early Eocene. Section 446-39-2 contains a diverse fauna of displaced shallow-water larger foraminifers, such as abundant Asterocyclina, Nummulites, Sphaerogypsina, etc., much like the fauna recovered from Section 445-53-4. Sediments in Core 446-40 suggest an age of early Eocene, possibly foraminifer Zones P.8/P.7. Basalt was encountered in 446-41,CC, and interspersed sediment layers of Eocene age were encountered in Cores 446-42 and 446-43. The foraminifers in Core 446-43 are badly worn, reworked, shallow-water benthic forms.

Hole 446A was washed down to a depth of 372 meters. Core 446A-1 contains a badly worn planktonic and benthic fauna of early Eocene age. Core 446A-2 recovered basalt, and from there on down the hole sediments interlayered with basalt sills were either barren or contained severely worn and crushed tests. Core 446A-13 contains a transported, shallow-water benthic fauna of Asterocyclina, Nummulites, Amphistegina, etc., similar to that recovered from Core 446-39. The accompanying planktonic forms are of late early Eocene age (approximately 51-52 m.y.).

\section{Summary}

In the Daito Ridge and Basin province, at Site 445, Holocene middle-Eocene sediments were penetrated. At Site 446, Holes 446 and 446 A were drilled from Pliocene into early middle Eocene and early middle Eocene through late early Eocene sediments, respectively. At both sites, post-Eocene sediments are pelagic, whereas Eocene sediments are resedimented clastic deposits. At Site 445 , the pelagic sediments are biogenic, with interbedded pyroclastic deposits, and at Site 446 they are non-biogenic and hemipelagic clays with interbedded pyroclastic deposits. The resedimented clastic deposits in the Eocene seem to be in general coarser at Site 445 than at Site 446.

At both sites, redeposited Eocene shallow-water larger foraminifers were recovered; this fauna is in- 
TABLE 3

Ranges of Selected Taxa for Possible Foraminifer Zonation, Daito Ridge and Basin Area

\begin{tabular}{|c|c|c|c|c|c|}
\hline Taxon & $\begin{array}{l}\text { Appearance } \\
\text { (Ma) }\end{array}$ & $\begin{array}{l}\text { Extinction } \\
\text { (Ma) }\end{array}$ & Taxon & $\begin{array}{l}\text { Appearance } \\
\text { (Ma) }\end{array}$ & $\begin{array}{l}\text { Extinction } \\
(\mathrm{Ma})\end{array}$ \\
\hline Globorotalia truncatulinoides & $1.9-2.0$ & Recent & G. velasconensis & 59 & 52 \\
\hline G. hirsuta & 2.5 & Recent & & & \\
\hline G. tosaensis & 3 & 0.600 & Globigerinoides fistulosus & 3.2 & 1.7 \\
\hline G. inflata & 3 & Recent & G. conglobatus & 6 & Recent \\
\hline G. ronda & 3 & 1.7 & G. ruber & 7.1 & Recent \\
\hline G. praehirsuta & 3.4 & 2.2 & G. obliquus extremus (S1) & 8 & 2 \\
\hline G. crassaformis & 4 & Recent & G. sacculifer & 19 & Recent \\
\hline G. praemiocenica & 4 & 1.9 & G. quadrilobatus triloba & 19 & Recent \\
\hline G. margaritae & 4 & 3.36 & G. subquadratus & 19 & 12 \\
\hline G. bononiensis & 4.2 & 3.1 & G. quadrilobatus (S1) & 22.5 & \\
\hline G. tumida & 5 & Recent & Globigerinoides sp. & 22.5 & \\
\hline G. humerosa & 6.9 & 2.5 & & & \\
\hline G. plesiotumida & 7.7 & $\sim 6$ & Globoquadrina altispira & 19 & 2.8 \\
\hline G. acostaensis & 10 & 2.5 & G. dehiscens group & 26 & 5.4 \\
\hline G. multicamerata & 10.5 & 2.7 & & & \\
\hline G. menardii (S1) & 14 & Recent & Pulleniatina finalis & 1.4 & Recent \\
\hline G. praemenardii & 15.5 & 14.5 & P. obliquiloculata & 3.7 & Recent \\
\hline G. scitula & 16 & Recent & $P$ primalis & 6.2 & 3.2 \\
\hline ? G. fohsi (S1) & 16 & 13 & & & \\
\hline G. kugleri & 25.5 & 20.5 & Sphaeroidinella dehiscens & 4.8 & Recent \\
\hline G. opima opima & 28 & 26 & S. paenedehiscens & 7.5 & 2.6 \\
\hline G. opima nana & 49 & 27 & S. subdehiscens & 12 & 6.2 \\
\hline G. increbescens & 49 & 31 & S. seminulina & 17.5 & 3.0 \\
\hline G. cerroazulensis (S1) & 49 & 37.5 & & & \\
\hline G. bullbrooki & 49 & 47 & Orbulina universa & 16 & Recent \\
\hline G. spinulosa & 51 & 44.5 & & & \\
\hline G. broedermanni & 56 & 47 & Praeorbulina glomerosa & 17 & 16 \\
\hline G. aragonensis & 52.5 & 47 & & & \\
\hline G. quetra & 53 & 49 & Globigerinita stainforthi & 20 & 17 \\
\hline & & & G. dissimilis & 45 & 18 \\
\hline Globigerina dutertrei & 3 & Recent & & & \\
\hline G. nepenthes & 11.2 & 3.7 & Globigerinatheka index & 47.5 & 41 \\
\hline G. angulisuturalis & 30 & 22 & G. barri? & 47.5 & 43 \\
\hline G. ampliapertura & 41 & 30 & G. mexicana? & 48 & 44 \\
\hline G. tripartita & 44.5 & 24 & G. subconglobata & 48.5 & 45.2 \\
\hline G. frontosa & 50 & 46 & & & \\
\hline G. senni & 51 & 44 & Globigerinatella insueta & 18.6 & 15.8 \\
\hline G. soldadoensis (S1) & 55 & 49 & & & \\
\hline G. primitiva & 56 & 45 & Truncorotaloides topilensis & 49 & 45 \\
\hline
\end{tabular}

dicative of a warm, shallow, carbonate environment and was no doubt derived from surrounding ridges.

Site 445 has been above the CCD during its depositional history, whereas at Site 446 deposition occurred very close to or below the CCD, with one brief fluctuation above the solution depth during the Oligocene.

\section{ACKNOWLEDGMENTS}

This paper has been reviewed by Mary Ann Rafle, Harold Levin, Rodey Batiza, and William Berggren.

\section{REFERENCES}

Banner, F. T., and Blow, W. H., 1965. Progress in the planktonic foraminiferal biostratigraphy of the Neogene. $\mathrm{Na}$ ture, 208, 1164.

Berggren, W. A., and Van Couvering, J. A., 1974. Biostratigraphy, geochronology and paleoclimatology of the last 15 million years in marine and continental sequences. Palaeogeography, Palaeoclimatology, Palaeoecology, 16, 1-216.
Blow, W. H., 1969. Late middle Eocene to Recent planktonic foraminifera biostratigraphy. In Brönniman, P., and Renz, H. H. (Eds.), Proceedings of the First International Conference Planktonic Microfossils (Vol. 6): Leiden (Brill), p. 199.

Bolli, H. M., 1957. Planktonic foraminifera from the Oligocene-Miocene Cipero and Lengua formations of Trinidad, B. W. I. Bull. U. S. Nat. Museum, 215.

1970. The foraminifera of Sites 23-31, Leg 4. In Bader, R. G., Gerard, R. D., et al., Init. Repts. DSDP, 4: Washington (U. S. Govt. Printing Office), p. 577.

Brönniman, P., and Resig, J., 1971. A Neogene globigerinacean biochronologic time scale of the southwestern Pacific. In Winterer, E. L., Moberly, R., et al., Init. Repts. DSDP, 7, Part 2: Washington (U. S. Govt. Printing Office), pp. 1235-1469.

Echols, D. J., and Schaeffer, K. M. M., 1960. Microforaminifera of the Marianna limestone (Oligocene) from Little Stave Creek, Alabama. Micropaleont. 6, 399.

Hanzawa, S., 1947. Eocene foraminifera from Haha-jima (Hillsborough Island). J. Paleont., 21, 254. 
Hardenbol, J., and Berggren, W. A., 1978. A new Paleogene numerical time scale. In Contributions to the Geologic Time Scale, AAPG Studies in Geology, No. 6, pp. 213-234.

Jenkins, D. G., 1966. Planktonic foraminiferal zones and new taxa from the Danian to lower Miocene of New Zealand. New Zealand J. Geol. Geophys., 8, 1088.

1967. Planktonic foraminiferal zones and new taxa from the lower Miocene to the Pleistocene of New Zealand. New Zealand J. Geol. Geophys., 10, 1064.

1971. New Zealand Cenozoic planktonic foraminifera. New Zealand Geol. Surv. Paleont. Bull., 42.

Jenkins, D. G., and Orr, W. N., 1972. Planktonic foraminiferal, biostratigraphy of the eastern equatorial Pacific DSDP Leg 9. In Worzel, J. L., Bryant, W., et al., Init. Repts. DSDP, 9: Washington (U. S. Govt. Printing Ofice), p. 1059.

Karig, D. E., 1975. Basin genesis in the Philippine sea. In Karig, D. E., Ingle, J. C., et al., Init. Repts. DSDP, 31: Washington (U. S. Govt. Printing Office), p. 857.

Kennett, J. P., 1973. Middle and late Cenozoic planktonic foraminiferal biostratigraphy of the southwest Pacific, DSDP Leg 21. In Burns, R. E., Andrews, J. E., et al., Init. Repts. DSDP, 21: Washington (U. S. Govt. Printing Office), p. 575.

1975. Late Cenozoic planktonic foraminifera and paleoceanography at DSDP Site 284 in the cool subtropical South Pacific. In Kennett, J. P., Houtz, R. E., et al., Init. Repts. DSDP, 29: Washington (U. S. Govt. Printing Office), p. 769.

Mizuno, A., and Konda, I., 1977. Eocene larger foraminifers from the sea floor near Oki-Daito-Shima Island (GH 74-7-167). Bull. Geol. Surv. Japan, 28, 639.

Mizuno, A., Okuda, Y., Tamaki, K., Kinoshita, Y., Nohara M., Yuasa, M., Nakajima, M., Murakami, F., Terashima, S., and Ishibashi, K., 1975. Marine geology and geological history of the Daito Ridge area, northwestern Philippine sea. Mar. Sci., 7, 484-491, 543-548.

Postuma, J. A., 1971. Manual of planktonic foraminifera: New York (Elsevier).

Saito, T., 1977. Late Cenozoic planktonic foraminiferal datum levels: the present state of knowledge toward accomplishing Pan-Pacific stratigraphic correlation. In Proceedings of the First International Congress on Pacific Neogene Stratigraphy: Tokyo, p. 61-80.

Shiki, T., Aoki, H., Suzuki, H., Masashino, M., and Okuda, Y., 1974. Geological and petrological results of the GDP-8 cruise in the Philippine Sea. Mar. Sci., 6, 51-55.

Stainforth, R. M., Lamb, J. L., Luterbacher, H., Beard, J. H., Jeffords, R. M., 1975. Cenozoic planktonic foraminiferal zonation and characteristics of index forms. Univ. Kansas Paleont. Contr., 62.

Ujiie, H., 1976. Prosphaeroidinella n. gen: probably ancestral taxon of Sphaeroidinellopsis (foraminifera). Bull. Nat. Sci. Museum, Ser. C. Geol. Paleont., 2, 9-26.

van Andel, T. H., Heath, G. R., Moore, T. C., Jr., 1975. Cenozoic history and paleooceanography of the central equatorial Pacific Ocean (a regional synthesis of Deep Sea Drilling Project data). Geol. Soc. Am. Mem., 143.

Vincent, E., 1975. Neogene planktonic foraminifera from the central North Pacific, Leg 32, Deep Sea Drilling Project. In Larson, R. L., Moberly, R. et al., Init. Repts. DSDP, 32: Washington (U. S. Govt. Printing Office), p. 765.

\section{APPENDIX 1}

\section{FORAMINIFERS FROM SITE 442, SHIKOKU BASIN}

Lat. $28^{\circ} 59.00^{\prime} \mathrm{N}$, Long. $136^{\circ} 03.43^{\prime} \mathrm{E}$; Water Depth 4639 meters (Holes 442, 442A), 4635 meters (Hole 442B).

\begin{tabular}{cccc}
\hline $\begin{array}{c}\text { Sample } \\
\text { (interval in cm) }\end{array}$ & $\begin{array}{c}\text { Depth Below } \\
\text { Sea Floor }(\mathrm{m})\end{array}$ & Age & Zone \\
\hline $442-1, \mathrm{CC}$ & 9.5 & Pleistocene & N.23
\end{tabular}
dominated by the fairly large, heavy-walled Globorotalia inflata, and these specimens show various stages of solution. Rare $G$. truncatulinoides and juvenile globigerinids. Benthic fauna: Melonis pompilioides, Lagena, Eponides, and Dorothia. At or just above the foraminifer solution depth.

$\begin{array}{lll}442 \mathrm{~A}-2-1,40-42 & 9.5 & \text { Pleistocene } \\ 442 \mathrm{~A}-2-3,41-43 & & \\ 442 \mathrm{~A}-2-5,40-42 & 19 & \\ 442 \mathrm{~A}-2, \mathrm{CC} & \end{array}$

Planktonic and benthic fauna poorly preserved, fragmented, showing solution effects. Dominant form G. inflata, rare G. humerosa, G. tosaensis? transitional to G. truncatulinoides, Globigerina bulloides, Globigerina sp., Globigerinoides conglobatus. Benthic fauna: Epistomina, Eponides, Uvigerina, Globobulimina. Reworking (?).

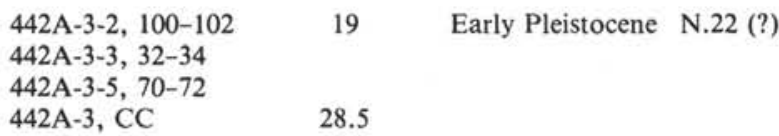

Moderate to poor preservation. G. inflata, G. truncatulinoides, $G$. tosaensis, Neogloboquadrina dutertrei, Globigerinoides ruber, Pulleniatina finalis, Globigerina sp., and juveniles. Benthic fauna: Uvigerina, Epistomina, Pyrgo, Cibicides. Slightly above foraminifer solution depth.

$442 \mathrm{~A}-4-1,130-132$
$442 \mathrm{~A}-4-3,50-52$
$442 \mathrm{~A}-4-5,26-28$
$442 \mathrm{~A}-4, \mathrm{CC}$

G. inflata, Globorotalia tumida, Globigerinoides, reworked Heterohelix. Benthic fauna: Tosaia?, Uvigerina, Cibicides, Epistomina, Pullenia, Eponides, Pyrgo, Melonis pompilioides, Fissurina. Sections 1,3 , and CC had very few, poorly preserved planktonic and benthic forms. Section 5 contained a moderately well preserved fauna with diverse benthic forms and many juveniles.

$\begin{array}{ll}442 \mathrm{~A}-5-1,69-71 & 38 \\ 442-5-3,90-92 & \\ 442 \mathrm{~A}-5-5,60-62 & \\ 442 \mathrm{~A}-5, \text { CC } & 47.5\end{array}$

Fragmented, very rare, poorly preserved $G$. inflata, Neogloboquadrina dutertrei, Pulleniatina. Benthic forms: Eponides, Pullenia.

442-6-1, 104-106

47.5

$442 \mathrm{~A}-6-3,60-62$

$442 \mathrm{~A}-6-5,67-69$

$442 \mathrm{~A}-6, \mathrm{CC}$

57

Very rare, fragmented $G$. inflata. At the solution depth. 


\begin{tabular}{cccc}
\hline $\begin{array}{c}\text { Sample } \\
\text { (interval in cm) }\end{array}$ & $\begin{array}{c}\text { Depth Below } \\
\text { Sea Floor (m) }\end{array}$ & Age & Zone \\
\hline $442 \mathrm{~A}-7-1,62-64$ & 57 & \\
$442 \mathrm{~A}-7-3,62-64$ & & \\
$442 \mathrm{~A}-7-6,62-64$ & 66.5 & \\
$442 \mathrm{~A}-7, \mathrm{CC}$ & & \\
As above. Rare, broken Cibicides and Eponides; rare microfora-
\end{tabular}
minifer fauna in Section 1.

442A-8-1, 50-52

66.5

$442 \mathrm{~A}-8-3,30-32$

$442 \mathrm{~A}-8-5,30-32$

$442 \mathrm{~A}-8, \mathrm{CC}$

76

Barren of foraminifers.

$\begin{array}{lc}\text { 442A-9-2, 90-92 } & 76 \\ \text { 442A-9, CC } & 85.5\end{array}$

Very rare foraminifer fragments.

442A-10-1, 30-32 85.5

442A-10-3, 30-32

442A-10, CC

95

Very rare G. inflata, G. tosaensis; tiny Melonis and Nonion in Section 1. Section 3 and CC barren. Solution effects obvious.

$\begin{array}{lc}442 \mathrm{~A}-11-3,9-11 & 95 \\ 442 \mathrm{~A}-11, \mathrm{CC} & 104.5\end{array}$

Barren.

442A-12-5, 19-21 $104.5 \quad \begin{gathered}\text { Pliocene/Pleisto- } \\ \text { cene }\end{gathered}$

442A-12, CC

Very rare forms showing dissolution: $G$. inflata, Globigerina bulloides, young Globigerinoides ruber, Pulleniatina.

442A-13-2, 105-107 $\quad 114$

442A-13, CC 123.5

Essentially barren; fragments.

442A-14-3, 67-69 $\quad 123.5$

442A-14, CC 133

Barren.

$442 \mathrm{~A}-15-1,121-123$

442A-15-3, 10-12

442A-15, CC

Barren.

$442 \mathrm{~A}-16-1,27-29 \quad 142.5$

442A-16, CC 152

Barren.

442A-17-1, 39-41 152

442A-17, CC 161.5

Barren.

$442 \mathrm{~A}-18-1,78-80$

442A-18-3, 29-31

Barren.

442A-19-1, 100-102

442A-19-3, 20-22

180.5

Barren.

\begin{tabular}{lccc}
\hline $\begin{array}{c}\text { Sample } \\
\text { (interval in cm) }\end{array}$ & $\begin{array}{c}\text { Depth Below } \\
\text { Sea Floor (m) }\end{array}$ & Age & Zone \\
\hline $\begin{array}{l}\text { 442A-20-1, 117-119 } \\
\text { 442A-20, CC }\end{array}$ & 180.5 & & \\
Barren. & 190 & & \\
442A-21-1, 90-92 & 190 & \\
442A-21-3, 66-68 & 199.5 & \\
Casts of foraminifers. & & \\
442A-22-1, 97-99 & 199.5 & \\
442A-22, CC & 209
\end{tabular}

As above, but common occurrence.

$\begin{array}{rr}442 \mathrm{~A}-23-1,33-35 & 209 \\ 442 \mathrm{~A}-23-3,33-35 & 218.5\end{array}$

442A-23, CC

As above. Abundant replaced casts, shapes more diverse.

$\begin{array}{lc}442 \mathrm{~A}-24-1,31-33 & 218.5 \\ 442 \mathrm{~A}-24-3,31-33 & 228\end{array}$

$442 \mathrm{~A}-24, \mathrm{CC}$

As above.

$\begin{array}{lc}442 \mathrm{~A}-25-3,41-43 & 228 \\ 442 \mathrm{~A}-25, \mathrm{CC} & 237.5\end{array}$

Rare casts of foraminifers.

$\begin{array}{lc}\text { 442A-26-2, 68-70 } & 237.5 \\ 442 \mathrm{~A}-26, \mathrm{CC} & 247\end{array}$

As above.

442A-27-2, 90-92 247

256.5

Very rare casts of foraminifers.

$\begin{array}{lr}\text { 442A-28-1, 37-39 } & 256.5 \\ \text { 442A-28-3, 66-68 } & \\ \text { 442A-28, CC } & 266\end{array}$

As above in Section 1. Section 3 and CC barren.

$\begin{array}{lc}\text { 442A-29-1, 19-21 } & 266 \\ \text { 442A-29-3, 92-94 } & \\ \text { 442A-29, CC } & 275.5\end{array}$

Barren.

$442 \mathrm{~A}-30-1,24-29$
$442 \mathrm{~A}-30-3,48-50$
$442 \mathrm{~A}-30, \mathrm{CC}$ (light
material)
$\begin{aligned} & 442 \mathrm{~A}-30, \mathrm{CC} \text { (dark } \\ & \text { material) }\end{aligned}$

Barren.

442A-31-1, 4-6

442A-31-1, 29-31

Barren.

442A-31

Thin section of limestone above basalt; outlines of replaced planktonic foraminifers.
442B-1-1, 134-136
267.5
442B-1-3, 25-27
$442 \mathrm{~B}-1, \mathrm{CC}$
277

Very rare casts and a few fragments of foraminifers. 


\begin{tabular}{cccc}
\hline $\begin{array}{c}\text { Sample } \\
\text { (interval in cm) }\end{array}$ & $\begin{array}{c}\text { Depth Below } \\
\text { Sea Floor (m) }\end{array}$ & Age & Zone \\
\hline $\begin{array}{l}\text { 442B-2-1, 0-2 } \\
\text { 442B-2-1, 7-9 }\end{array}$ & 277 & Miocene & N.11 \\
442B-2-3, 38-40 & & & \\
442B-2, CC & 286.5 & &
\end{tabular}

Rare, partially dissolved planktonic forms resembling Sphaeroidinellopsis subdehiscens with cortex dissolved away. However these forms may belong to Ujiie's Prosphaeroidinella. (See text.) Benthic forms very rare and show solution: Nonion, Eponides, Gyroidina, Globocassidulina.
442B-9, CC
353
Miocene N.6 (?)

Poorly preserved, partially dissolved and squashed: Catapsydrax dissimilis, ?Globorotalia obesa, and Globigerina sp. Benthic forms: Eponides, Bolivina, Globocassidulina.

$\begin{array}{ccc}442 \mathrm{~B}-20 & 445.5 & \text { Miocene } \\ 442 \mathrm{~B}-20 & 455 & \end{array}$

Second re-entry. Fragments and casts of planktonic foraminifers. This sample is unreliable; it was taken from loose sediment around a pebble of basalt.

\section{APPENDIX 2 \\ FORAMINIFERS FROM SITE 443, SHIKOKU BASIN}

Lat. $29^{\circ} 19.65^{\prime} \mathrm{N}$, Long. $137^{\circ} 26.43^{\prime} \mathrm{E}$; Water Depth 4372 meters.

\begin{tabular}{cccc}
\hline $\begin{array}{c}\text { Sample } \\
\text { (interval in cm) }\end{array}$ & $\begin{array}{c}\text { Depth Below } \\
\text { Sea Floor (m) }\end{array}$ & Age & Zone \\
\hline $433-1,35-37$ & 0 & Pleistocene & N.23 \\
$433-1-3,31-33$ & & & \\
$433-1-5,34-36$ & & & \\
$433-1$, CC & & &
\end{tabular}

Few moderately to poorly preserved foraminifers. Planktonic fauna: Globorotalia inflata, G. truncatulinoides, G. tumida, G, hirsuta, Globigerinoides sacculifer, G. ruber, Neogloboquadrina dutertrei, G. bulloides, G. pachyderma, Pulleniatina obliquiloculata, and Hasterigerina. Benthic fauna: Pyrgo, Quinqueloculina, Uvigerina, and Caribeanella.

$$
\begin{aligned}
& 433-2-1,86-88 \\
& 433-2-3,108-110
\end{aligned}
$$$$
\text { 443-2, CC }
$$

Section 1 barren of foraminifers. Section 3 and CC contained fairly numerous planktonic and benthic fauna. Preservation better than in Core 1 but still much fragmentation. However, there are many fragile juvenile benthics intact. Planktonic fauna: Globorotalia inflata, $G$. tumida, G. hirsuta, G. truncatulinoides, Globigerinoides sacculifer, Globigerina bulloides, G. dutertrei, Hasterigerina aequilateralis, Pulleniatina, and Orbulina universa. Benthic fauna: Eponides, Melonis, Epistomina, Uvigerina, Pyrgo, Quinqueloculina.

$443-3-1,20-22 \quad 16.5 \quad$ Pleistocene
$443-3-3,48-50$
$443-5,43-45$

Moderately well to poorly preserved, fragmented planktonic forms. Increase in benthic forms, which are, on the whole, better preserved than the planktonic forms. Planktonic fauna: Globorotalia inflata, G. truncatulinoides, G. tumida, G. menardii, Globigerinoides trilobata, G. conglobatus, Globigerina dutertrei, Orbulina, and Pulleniatina. Benthic fauna: common Uvigerina, fairly common Pyrgo; other benthic forms are Epistomina, Cibicides, Fissurina, Eponides, Triloculina, and Stainforthia.

\begin{tabular}{cccc}
\hline $\begin{array}{c}\text { Sample } \\
\text { (interval in cm) }\end{array}$ & $\begin{array}{c}\text { Depth Below } \\
\text { Sea Floor }(\mathrm{m})\end{array}$ & Age & Zone \\
\hline $\begin{array}{l}443-4-1,81-83 \\
443-4-3,57-59\end{array}$ & 26 & Pleistocene & \\
$443-4$, CC & 35.5 & &
\end{tabular}

Planktonic foraminifers show various degrees of dissolution and fragmentation. Section 1 contained the most abundant and diverse fauna. Globorotalia inflata (dominant), G. truncatulinoides, G. hirsuta, G. tumida, Globigerinoides conglobatus, Globigerina bulloides, G. dutertrei, Pulleniatina, and Orbulina. Benthic fauna (on the whole better preserved): Uvigerina (common), Pyrgo, Eponides, Epistomina, Fissurina, Cibicides, and ?Tosaia.

$\begin{array}{lcc}443-5-1,46-48 & 35.5 & \text { Pleistocene } \\ 443-5-3,90-92 & & \\ 443-5, \text { CC } & 45 & \end{array}$

Foraminifers in Sections 1 and 3 moderately to poorly preserved; fragmentation indicates solution. The core catcher section, mostly volcanic glass, contained very rare foraminifers. Microforaminifersize forms in the three samples. Fauna as above, plus Globigerinoides sacculifer and Sphaeroidinella dehiscens.

$\begin{array}{lccr}433-6-1,107-109 & 45 & \text { Pleistocene } & \text { N.22 } \\ 443-6-3,56-58 & & & \\ 443-6-5,27-29 & 54.5 & \\ 443-6, \text { CC } & & \end{array}$

Sections 1 and 5 and CC contain very rare planktonic and benthic forms. In Section 3, foraminifers more common, Globorotalia inflata still the dominant species. The assemblage and preservation similar to cores above.
443-7-6, 66-68
54.5
443-7, CC
64

The large number of broken chambers and fragments of planktonic forms indicates a sizeable population before dissolution. Globorotalia inflata still dominates the fauna, with a fair number of Sphaeroidinella dehiscens. A few broken forms transitional to Globorotalia tosaensis. Benthic forams indicate deep water.
443-8-4, 40-42
443-8, CC
64

Very sparse foraminifer fauna.

$\begin{array}{ll}443-9-1,50-52 & 73.5 \\ 443-9-3,50-52 & \\ 443-9-5,50-52 & 83 \\ 443-9, \text { CC } & \end{array}$

Sparse, fragmented fauna. Globorotalia tosaensis and the benthic genus Burseola. In Section 5 and the CC some very large, thickwalled, agglutinated forms were found, tentatively assigned to Hemisphaerammina. Benthic forms indicate deep water.
443-10-1, 57-59
$443-10-2,126-128$
443-10-3, 6-8
443-10-5, 6-8

83

The sections examined contain an extremely rare, fragmented fauna. The core catcher contained a more representative fauna, fairly common fragments and tiny forms.

$443-11-3,84-86$

$$
92.5
$$

443-11, CC

Section 5 and CC barren. In Section 3, Globorotalia inflata still dominates population. G. tumida, G. tosaensis?, Globigerinoides, and Sphaeroidinella present in varying stages of dissolution. Few small benthic forms also fragmented. 


\begin{tabular}{cccc}
\hline $\begin{array}{c}\text { Sample } \\
\text { (interval in cm) }\end{array}$ & $\begin{array}{c}\text { Depth Below } \\
\text { Sea Floor }(\mathrm{m})\end{array}$ & Age & Zone \\
\hline $443-12-1,40-42$ & 102 & Pliocene & N.21 \\
$443-12$, CC & 111.5 & &
\end{tabular}

Fauna similar to above. Few specimens of Pulleniatina praecursor, increase in number of Sphaeroidinella.

$$
\text { 443-13, CC 115-121 }
$$

Essentially barren. A few specimens of fragmented planktonic and benthic forms.

$$
\begin{array}{ll}
443-14-4,40-42 & 121 \\
443-14-5,124-126 & 28
\end{array}
$$

Barren.

$443-15-3,19-21$

$443-15-5,19-21$

130.5

$443-15$, CC

Barren.

443-16, CC

Barren.

$\begin{array}{lc}443-17-3,134-136 & 149.5 \\ 443-17, \text { CC } & 159\end{array}$

Very, very rare, fragmented benthic forms.

$\begin{array}{ll}443-18-1,50-52 & 159 \\ 443-18-3,50-52 & \end{array}$

$443-18$, CC

As above.

$\begin{array}{lc}443-19-1,40-42 & 168.5 \\ 443-19, \text { CC } & 178\end{array}$

Essentially barren, one or two fragments.

$\begin{array}{lc}443-20-1,50-52 & 178 \\ 443-20-3,10-12 & \\ 443-20, \text { CC } & 187.5\end{array}$

As above.

$443-21-1,30-32 \quad 187.5$

443-21, CC

Barren.

443-22-1, 17-19

443-22-2, 108-110

206.5

Very rare benthic forms: nodosarid fragments, Globocassidulina, Eponides, and Pullenia.

$\begin{array}{ll}443-23-1,67-69 & 206.5 \\ 443-23-3,10-12 & \\ 443-23-5,1-3 & \\ 443-23, \text { CC } & 215\end{array}$

Very rare, fragmented benthic forms. Planktonic ?Pulleniatina praecursor.

$$
\begin{array}{ll}
443-24-1,99-101 & 216 \\
443-24-3,58-60 & \\
443-24-5,100-102 & \\
443-24, \text { CC } & 225.5
\end{array}
$$

Very rare benthic forms, poor preservation. Laticarina, Eponides, Globocassidulina.

\begin{tabular}{cccc}
\hline $\begin{array}{c}\text { Sample } \\
\text { (interval in cm) }\end{array}$ & $\begin{array}{c}\text { Depth Below } \\
\text { Sea Floor }(\mathrm{m})\end{array}$ & Age & Zone \\
\hline $\begin{array}{l}443-25-2,8-10 \\
443-25-3,72-74\end{array}$ & 225.5 & & \\
\end{tabular}

Essentially barren, a few benthic specimens of Stilostomella.

$\begin{array}{lr}443-26-1,101-103 & 235 \\ 443-26, \text { CC } & 244.5\end{array}$

Extremely rare, fragmented benthic forms.

443-27-1, 94-96

244.5

443-27-3, 78-80

443-27, CC

254

Barren.

443-28-1, 60-62

443-28, CC

254

Barren.

443-29-1, 35-37

443-29-3, 35-37

443-29-5, 35-37

443-29, CC

Barren.

443-30-2, 56-58

273-282.5

Barren.

443-31-1, 128-130

443-31-3, 6-8

$443-31-5,6-8$

443-31, CC

Barren.

443-32, CC

292-301.5

Rare benthic forms.

$\begin{array}{lc}443-33-1,120-122 & 301.5 \\ 443-33, \text { CC } & 311\end{array}$

Extremely rare benthic forms.

$$
\begin{array}{lc}
443-34-1,117-119 & 311 \\
443-34-3,117-119 & 320.5
\end{array}
$$

Few benthic forms, dominated by Siphonodosaria.

$$
\begin{array}{lc}
443-35-1,34-36 & 320.5 \\
443-35, \text { CC } & 330
\end{array}
$$

Very rare benthic forms.

$$
\begin{aligned}
& 443-36-1,46-48 \\
& 443-36-3,41-43 \\
& 443-36-5,40-42
\end{aligned}
$$

443-36, CC

339.5

As above.

$\begin{array}{lc}443-37-1,120-122 & 339.5 \\ 443-37, \text { CC } & 349\end{array}$

As above.

443-38-1, 95-97 349

443-38, CC 358.5

Barren. 


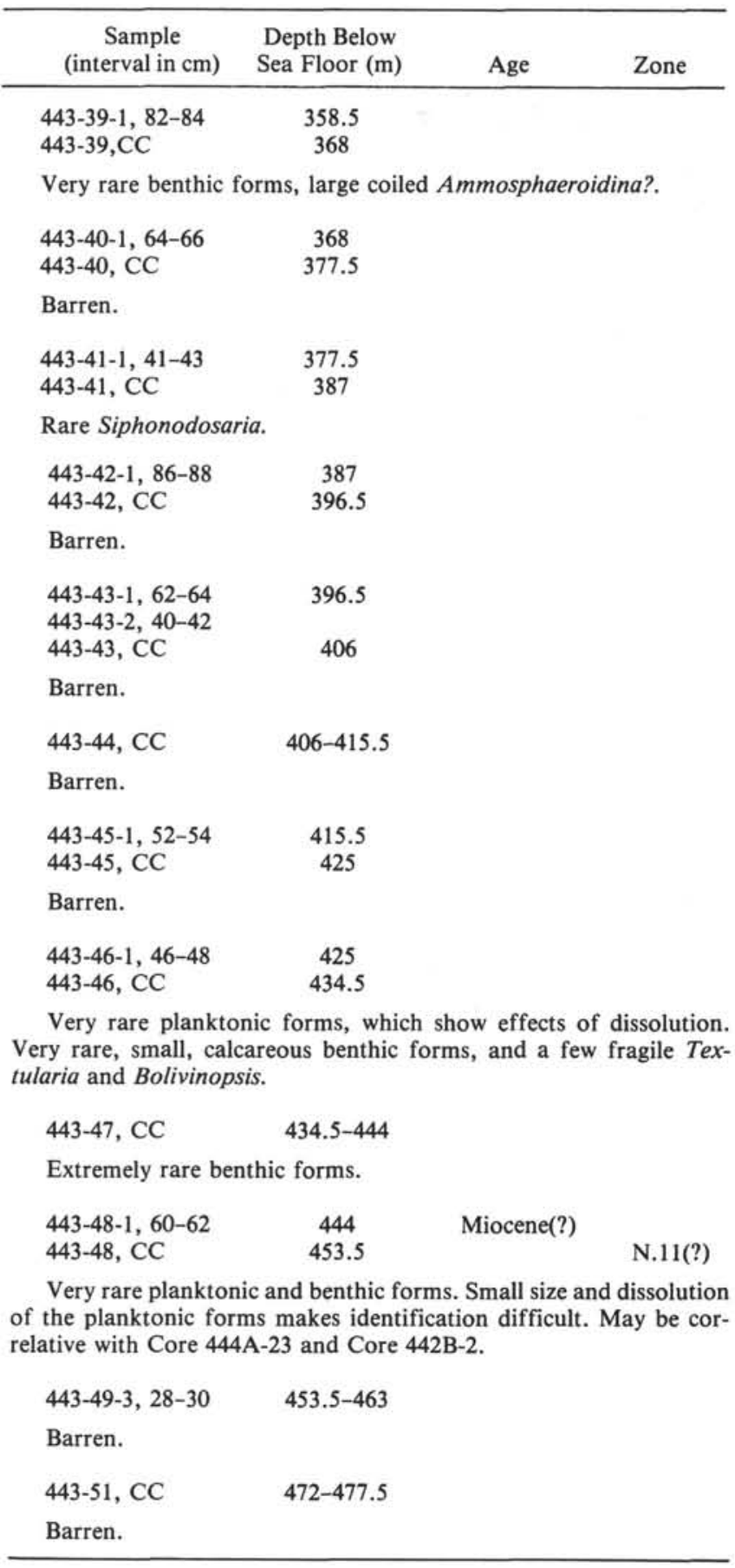

\section{APPENDIX 3 \\ FORAMINIFERS FROM SITE 444, SHIKOKU BASIN}

Lat. $28^{\circ} 38.25^{\prime} \mathrm{N}$, Long. $137^{\circ} 41.03^{\prime} \mathrm{E}$; Water Depth 4843 meters.

\begin{tabular}{cccc}
\hline $\begin{array}{c}\text { Sample } \\
\text { (interval in cm) }\end{array}$ & $\begin{array}{c}\text { Depth Below } \\
\text { Sea Floor }(\mathrm{m})\end{array}$ & Age & Zone \\
\hline $444-1, \mathrm{CC}$ & 9.5 & Pleistocene \\
\multicolumn{4}{c}{ A poorly preserved and sparse planktonic fauna of Globorotalia } \\
inflata, G. truncatulinoides, Neogloboquadrina pachyderma, G. \\
bulloides, Hastigerina, Pulleniatina. Rare benthic forms include Epo- \\
nides, Cibicides, and Paradentalina.
\end{tabular}

\begin{tabular}{cccc}
\hline $\begin{array}{c}\text { Sample } \\
\text { (interval in cm) }\end{array}$ & $\begin{array}{c}\text { Depth Below } \\
\text { Sea Floor }(\mathrm{m})\end{array}$ & Age & Zone \\
\hline $\begin{array}{l}444-2-1,88-90 \\
444-2-3,77-79\end{array}$ & 9.5 & Pleistocene & \\
$444-2-5,69-71$ & & & \\
$444-2$, CC & 19 &
\end{tabular}

As above, plus few specimens of planktonic Globigerinoides ruber and Globorotalia menardii and benthic Epistomina, Globocassidulina, Pyrgo, and Quinqueloculina.

$\begin{array}{llll}444-3-1,27-29 & 19 & \text { Pleistocene } & \text { N.22 } \\ \begin{array}{l}444-3-3,2-4 \\ 444-3, \text { CC }\end{array} & 28.5 & & \end{array}$

As above.

$\begin{array}{llll}444-4-1,49-51 & 28.5 & \text { Pleistocene } & \text { N.22 } \\ 444-4-3,47-49 & & & \\ 444-4-5,4-6 & 38 & & \\ 444-4, \text { CC } & 38\end{array}$

Very rare Globorotalia inflata. Small benthics include Uvigerina, Globocassidulina, Melonis, Pyrgo and Epistomina.

$\begin{array}{llll}444-5-1,30-32 & 38 & \text { Pleistocene } & \text { N.22 } \\ 444-5-3,30-32 & 47.5 & & \\ 444-5, \text { CC } & 47 & \end{array}$

Rare, severely dissolved planktonic forms include Globorotalia inflata, G. hirsuta, G. humerosa, and G. tumida. Numerous chamber fragments indicate population destroyed due to proximity to CCD. Rare benthic forms.

$\begin{array}{llcc}444-6-1,35-37 & 47.5 & \text { Early Pleistocene } & \text { N.22 } \\ 444-6, \text { CC } & 57 & \text { Late Pliocene } & \text { N.21 }\end{array}$

Moderately well to poorly preserved. Globorotalia inflata dominant, $G$. tosaensis and Sphaeroidinella dehiscens present. Benthic fauna: Pullenia, Cibicides, and Globocassidulina.

$\begin{array}{llll}444-7-2,40-42 & 57 & \text { Late Pliocene } & \text { N.21 } \\ \begin{array}{l}444-7-3,108-110 \\ 444-7-6,43-45\end{array} & & \\ 444-7, \text { CC } & 66.5 & \end{array}$

Very rare and poorly preserved Globorotalia inflata and $G$. tumida. Benthic forms include Cibicides and Uvigerina.

\section{Sample}

$\begin{array}{llll}444-8-1,56-58 & 66.5 & \text { Late Pliocene } & \text { N.21 }\end{array}$

$444-8$, CC

Essentially barren.

$\begin{array}{ll}\text { 444-9-1, 101-103 } & 76 \\ 444-9-1,104-106 & 85.5\end{array}$

Barren of calcareous forms. However, a deep-water, agglutinated benthic fauna of Bathysiphon, Rheophax, ?Cyclammina japonica, Haplophragmoides, Hyperammina, Sphaerammina?, and Saccammina is present.

$\begin{array}{ll}\text { 444-10-1, 86-86 } & 85.5 \\ \begin{array}{l}444-10-2,126-128 \\ \text { 444-10, CC }\end{array} & 95 \\ \text { As above. } & \\ & \\ 444 A-1-1,145-147 & 82 \\ \text { 444A-1-3, 16-18 } & \\ 444 A-1-5,16-18 & \\ 444 A-1, \text { CC } & 91.5\end{array}$

A few fragments of planktonic forms and rare benthic forms. A fair number of tiny forms, juveniles or microforaminifers. 


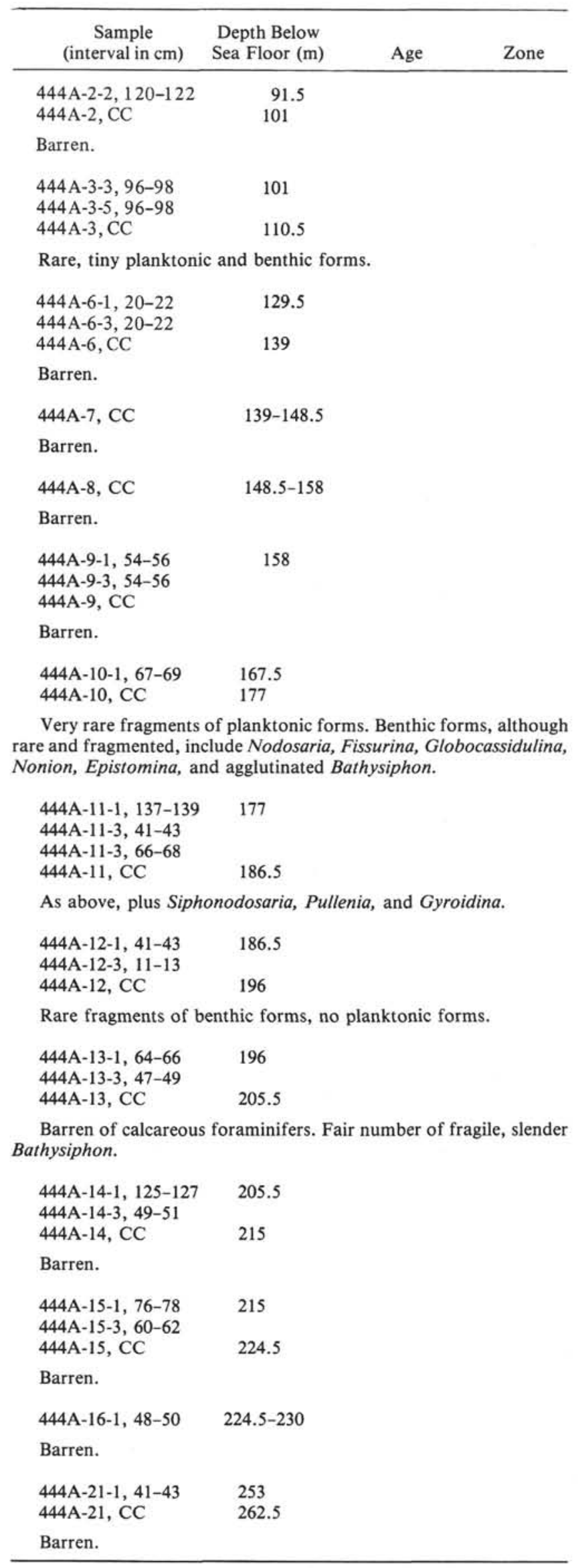

\begin{tabular}{|c|c|c|c|}
\hline $\begin{array}{c}\text { Sample } \\
\text { (interval in } \mathrm{cm} \text { ) }\end{array}$ & $\begin{array}{l}\text { Depth Below } \\
\text { Sea Floor }(m)\end{array}$ & Age & Zone \\
\hline $\begin{array}{l}444 A-22-1,14-16 \\
444 A-22-3,27-28 \\
444 A-22-4,74-76 \\
444 A-22, C C\end{array}$ & 262.5 & & \\
\hline \multicolumn{4}{|l|}{ Barren. } \\
\hline $444 \mathrm{~A}-23-1,19-20$ & $272-278.5$ & $\begin{array}{l}\text { Middle (?) } \\
\text { Miocene }\end{array}$ & N.11 (?) \\
\hline \multicolumn{4}{|l|}{$\begin{array}{l}\text { Rare, fragmented, } \\
\text { forms questionable be } \\
\text { this sample appears } t \\
\text { Deep water benthic fo }\end{array}$} \\
\hline
\end{tabular}

\section{APPENDIX 4 FORAMINIFERS FROM SITE 445, DAITO RIDGE}

Lat. $25^{\circ} 31.36^{\prime} \mathrm{N}$, Long. $133^{\circ} 12.49^{\prime} \mathrm{E}$; Water Depth 3377 meters.

Abundance (specimens per tray) determined at low magnification $(\times 30)$; the following symbols are used:

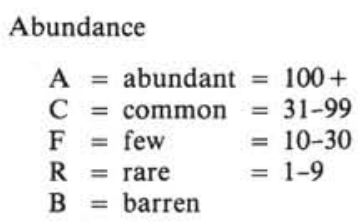

Preservation

$$
\begin{aligned}
& \mathrm{G}=\text { good } \\
& \mathrm{M}=\text { moderately good } \\
& \mathrm{P}=\text { poor }
\end{aligned}
$$

Other

$$
\begin{aligned}
& \mathrm{b}=\text { benthic forms } \\
& \mathrm{Pl}=\text { planktonic forms } \\
& \mathrm{T}=\text { tiny foraminifers (juveniles or microforaminifers) } \\
& >=\text { decrease } \\
& \mathrm{S}=\text { size } \\
& \mathrm{D}=\text { diversity }
\end{aligned}
$$

\begin{tabular}{lccc}
\hline $\begin{array}{l}\text { Depth Below } \\
\text { (interval in } \mathrm{cm})\end{array}$ & $\begin{array}{c}\text { Sea Floor } \\
(\mathrm{m})\end{array}$ & $\begin{array}{l}\text { Faunal } \\
\text { Aspects }\end{array}$ & Zone \\
\hline
\end{tabular}

$$
\begin{aligned}
& 445-1-1,79-81 \\
& 445-1-2,79-81 \\
& 445-1-3,37-39 \\
& 445-1-4,45-47 \\
& 445-1-5,5-7 \\
& 445-1-6,71-73 \\
& 445-1, \text { CC }
\end{aligned}
$$

A G b
A G b
A G b
A G b
A G b
A G b
A G b

445-2-1, 32-34

$445-2-2,38-40$

$445-2-3,11-13$

$445-2-4,34-36$

445-2, CC

A G b

N. 23

$A G$ b

A G b

A G b

A G b

A G b

$\mathrm{AM} \mathrm{b}>\mathrm{S}$

$\mathrm{A} \mathrm{M} \mathrm{b}$

$\mathrm{CM} \mathrm{b}>\mathrm{D}$

$\mathrm{A} \mathrm{M} \mathrm{b}$ 


\begin{tabular}{|c|c|c|c|c|c|c|c|}
\hline $\begin{array}{l}\text { Sample } \\
\text { (interval in } \mathrm{cm} \text { ) }\end{array}$ & $\begin{array}{l}\text { Depth Below } \\
\text { Sea Floor } \\
\text { (m) }\end{array}$ & $\begin{array}{l}\text { Faunal } \\
\text { Aspects }\end{array}$ & Zone & $\begin{array}{l}\text { Sample } \\
\text { (interval in } \mathrm{cm} \text { ) }\end{array}$ & $\begin{array}{l}\text { Depth Below } \\
\text { Sea Floor } \\
\text { (m) }\end{array}$ & $\begin{array}{l}\text { Faunal } \\
\text { Aspects }\end{array}$ & Zone \\
\hline $445-3-1,120-122$ & & $\mathrm{~A} \mathrm{G} \mathrm{b}$ & & $445-12-1,40-42$ & & $\mathrm{FM}>\mathrm{S}$ & \\
\hline $445-3-2,84-86$ & & $A G$ b & & $445-12-3,40-42$ & & $\mathrm{C} M>\mathrm{S}$ & \\
\hline $445-3-3,70-72$ & & $A G$ b & & $445-12-4,40-42$ & & $\mathrm{CM}>\mathrm{S}$ & \\
\hline $445-3-4,69-71$ & & $\mathrm{AG} \mathrm{b}$ & & $445-12, \mathrm{CC}$ & 113 & $\mathrm{FM}>\mathrm{S}$ & \\
\hline $445-3-5,31-33$ & & $A G$ b & & & & & \\
\hline $445-3-6,119-121$ & & A G b & & & & & \\
\hline $445-3-7,14-16$ & & $\mathrm{CG} \mathrm{b}>\mathrm{S}$ & & $445-13-1,92-94$ & & $\mathrm{R} P \mathrm{P} A \mathrm{~T}$ & \\
\hline \multirow[t]{3}{*}{$445-3, \mathrm{CC}$} & 27.5 & A G b & & $445-13-2,92-94$ & & & \\
\hline & & & & $445-13-3,92-94$ & & $\mathrm{CMb}>\mathrm{S}$ & \\
\hline & & & & $445-13-4,92-94$ & & & N.19(?) \\
\hline $445-4-2,45-47$ & & $\begin{array}{l}C G \text { b } \\
A G \text { b }\end{array}$ & & $445-13, \mathrm{CC}$ & 122.5 & $\mathrm{C} \mathrm{M} \mathrm{b}$ & \\
\hline $445-4-3,45-47$ & & $\mathrm{CM} \mathrm{b}$ & & & & & \\
\hline $445-4-4,45-47$ & & $\mathrm{~A} \mathrm{G} \mathrm{b}$ & & $445-14-1,52-54$ & & $\mathrm{FM}>\mathrm{S} \mathrm{T}$ & \\
\hline $445-4-5,45-47$ & & $\mathrm{CM} \mathrm{b}$ & & $445-14, C C$ & 132 & $\mathrm{FM} \mathrm{b} \mathrm{T}$ & \\
\hline $445-4-6,47-49$ & & $\mathrm{C} \mathrm{M} \mathrm{b}$ & & & & & \\
\hline $445-4, C C$ & 37 & $\mathrm{C} \mathrm{G} \mathrm{b}$ & N. 22 & & & & \\
\hline & & & & $445-15-1,50-52$ & & $\mathrm{FM}>\mathrm{S} \mathrm{T}$ & \\
\hline & & & & $445-15-2,50-52$ & & $\mathrm{CG}>\mathrm{ST}$ & \\
\hline $445-5-1,26-28$ & & $\mathrm{CM}>\mathrm{b}$ & & $445-15, \mathrm{CC}$ & 141.5 & $\mathrm{CM}>\mathrm{S}$ & N.18(?) \\
\hline $445-5-2,26-28$ & & $A G>b$ & & & & & \\
\hline $445-5-3,26-28$ & & $\mathrm{AM}>\mathrm{b}$ & N. 21 & & & & \\
\hline \multirow[t]{3}{*}{$445-5, \mathrm{CC}$} & 46.5 & $A G$ b & & $445-16-1,56-58$ & & B $T ?$ & \\
\hline & & & & $445-16-2,56-58$ & & $\mathrm{~B} \mathrm{~T}$ ? & \\
\hline & & & & $445-16-3,56-58$ & & $\mathrm{AG} \mathrm{b} \mathrm{T}$ & \\
\hline $445-6-1,48-50$ & & A M b T & & $445-16-4,56-58$ & & A G b & \\
\hline $445-6-2,48-50$ & & $\mathrm{~A} \mathrm{G} \mathrm{b}$ & & $445-16, C C$ & 151 & $A G b$ & \\
\hline $445-6-3,48-50$ & & $\mathrm{AM} \mathrm{b}$ & & & . & & \\
\hline $445-6-4,48-50$ & & $\mathrm{~A} \mathrm{M} \mathrm{b}$ & & & & & \\
\hline $445-6-5,48-50$ & & $\mathrm{~A} \mathrm{G} \mathrm{b}$ & & $445-17-1,52-54$ & & $\mathrm{C} \mathrm{G}$ & \\
\hline $445-6-6,48-50$ & & A G b & & $445-17, \mathrm{CC}$ & 160.5 & $\mathrm{C} M$ & \\
\hline \multirow[t]{2}{*}{$445-6, \mathrm{CC}$} & 56 & $\mathrm{~A} \mathrm{M} \mathrm{b}$ & & & & & \\
\hline & & & & $445-18-1,12-14$ & & A G & \\
\hline $445-7-2,38-40$ & & A M b T & & $445-18-2,12-14$ & & A G & \\
\hline $445-7-5,38-40$ & & A M b & & $445-18-3,12-14$ & & $\mathrm{CG}$ & \\
\hline $445-7-6,38-40$ & & $\mathrm{C} \mathrm{M} \mathrm{b}$ & & $445-18-4,12-14$ & & F M & \\
\hline \multirow[t]{2}{*}{$445-7$, CC } & 65.5 & $\mathrm{~A} \mathrm{G} \mathrm{b}$ & N. 21 & $445-18-5,12-14$ & & R P T & \\
\hline & & & & $445-18, \mathrm{CC}$ & 170 & $\mathrm{~F} \mathrm{M} \mathrm{T}$ & N.17 \\
\hline $445-8-1,20-22$ & & F G b & & & & & \\
\hline $445-8-2,20-22$ & & $\mathrm{C} \mathrm{M} \mathrm{b}$ & & $445-19-1,69-71$ & & $\mathrm{C} \mathrm{G}$ & \\
\hline $445-8-3,20-22$ & & $\mathrm{R} \mathrm{P} \mathrm{b}$ & & $445-19-2,69-71$ & & $\mathrm{CM}$ & \\
\hline $445-8-4,20-22$ & & R P b T & & $445-19-3,69-71$ & & $\mathrm{~F} \mathrm{M} \mathrm{T}$ & \\
\hline $445-8-4,45-47$ & & A G b & & $445-19$, CC & 179.5 & $\mathrm{C} \mathrm{G}$ & \\
\hline $445-8-5,20-22$ & & F M & & & & & \\
\hline $445-8-6,20-22$ & & R P C T b & & & & & \\
\hline \multirow[t]{3}{*}{$445-8-6,45-47$} & 75 & $A G$ b $>S$ & & $445-20-1,70-72$ & & $\mathrm{C} \mathrm{G} \mathrm{b}$ & \\
\hline & & & & $445-20-2,70-72$ & & $\mathrm{~A} \mathrm{G} \mathrm{b}$ & \\
\hline & & & & $445-20$, CC & 189 & $\mathrm{CM} \mathrm{b}$ & \\
\hline \multirow[t]{2}{*}{$445-9, \mathrm{CC}$} & 84.5 & $\mathrm{CM}$ & & & & & \\
\hline & & & & $445-21-1,95-97$ & & $\mathrm{CM} \mathrm{b}$ & \\
\hline $445-10-1,40-42$ & & $\mathrm{~A} \mathrm{G} \mathrm{b}$ & & $445-21-2,95-97$ & & $\mathrm{CM} \mathrm{b}$ & \\
\hline $445-10-2,40-42$ & & A M b & & $445-21, \mathrm{CC}$ & 198.5 & $\mathrm{CM} \mathrm{b}$ & \\
\hline $445-10-3,40-42$ & & $\mathrm{~A} \mathrm{M} \mathrm{b}$ & & & & & \\
\hline $445-10-4,40-42$ & & $\mathrm{~A} \mathrm{M} \mathrm{b}$ & & $445-22-1,20-22$ & & $\mathrm{CM} \mathrm{b}$ & \\
\hline $445-10-5,40-42$ & & $A G$ b $>S$ & & $445-22-2,19-21$ & & $\mathrm{CG} \mathrm{b}$ & \\
\hline $445-10, C$ & 94 & $\mathrm{CG} \mathrm{b}$ & & $445-22, \mathrm{CC}$ & 208 & $\mathrm{~F} \mathrm{M} \mathrm{b}$ & \\
\hline $445-11-2,50-52$ & & $\mathrm{~A} \mathrm{G} \mathrm{b}$ & & $445-23-1,120-122$ & & $\mathrm{R}$ b $\mathrm{P}$ & \\
\hline $445-11-3,50-52$ & & $\mathrm{C} \mathrm{M} \mathrm{b}$ & & $445-23-2,120-122$ & & F P & \\
\hline $445-11-4,50-52$ & & F M T & & $445-23-3,120-122$ & & $\mathrm{AMT}$ & \\
\hline $445-11$, CC & 103.5 & $\mathrm{C} \mathrm{M} \mathrm{b}$ & & $445-23, \mathrm{CC}$ & 217.5 & $\mathrm{R} \mathrm{M}$ & \\
\hline
\end{tabular}




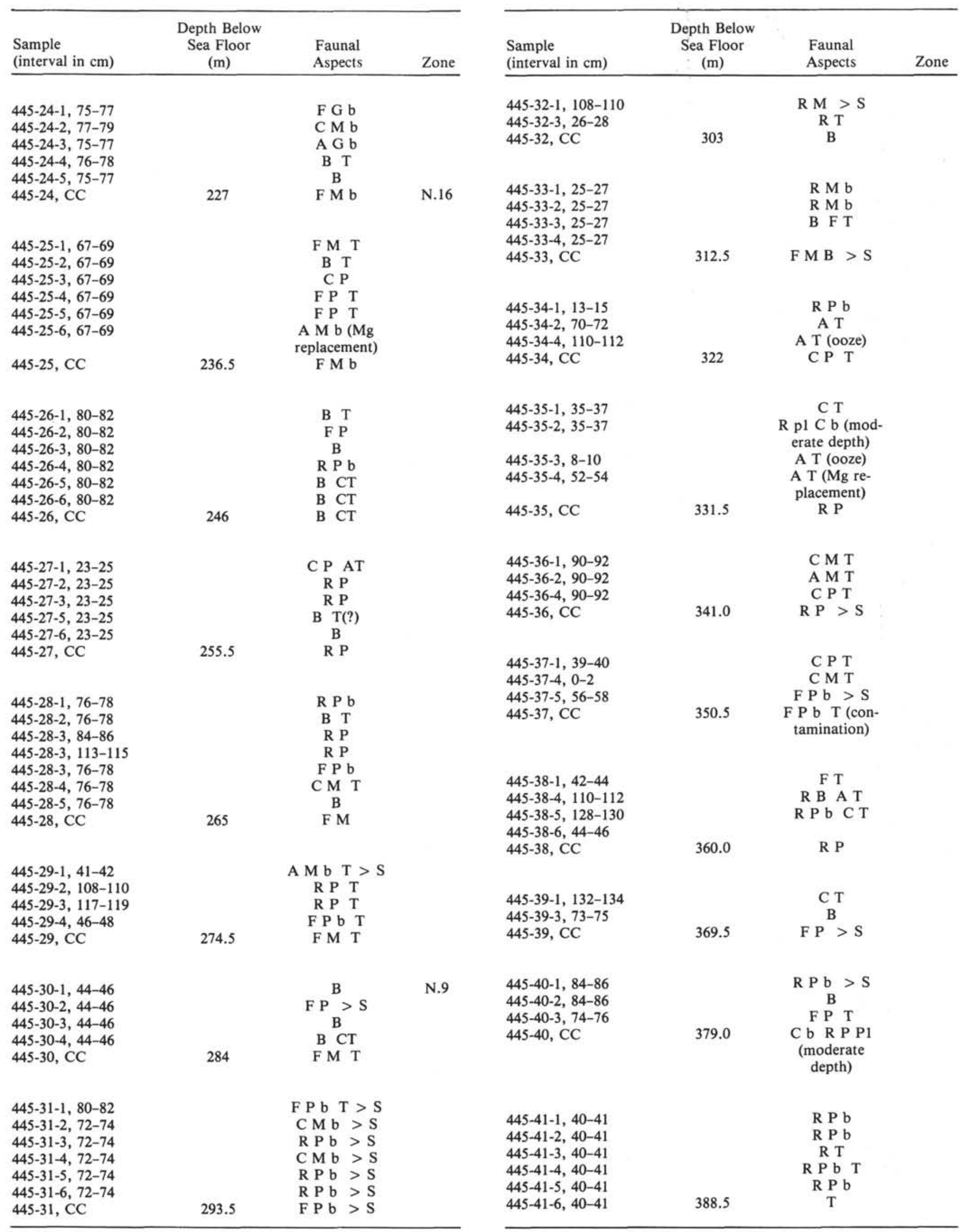




\begin{tabular}{|c|c|c|c|c|c|c|c|}
\hline $\begin{array}{l}\text { Sample } \\
\text { (interval in } \mathrm{cm} \text { ) }\end{array}$ & $\begin{array}{l}\text { Depth Below } \\
\text { Sea Floor } \\
\text { (m) }\end{array}$ & $\begin{array}{l}\text { Faunal } \\
\text { Aspects }\end{array}$ & Zone & $\begin{array}{l}\text { Sample } \\
\text { (interval in cm) }\end{array}$ & $\begin{array}{l}\text { Depth Below } \\
\text { Sea Floor } \\
(\mathrm{m})\end{array}$ & $\begin{array}{l}\text { Faunal } \\
\text { Aspects }\end{array}$ & Zone \\
\hline $445-42-1,17-18$ & & $\mathrm{RPb}>\mathrm{S}$ & & $445-51-1,8-10$ & & B & \\
\hline $445-42-2,17-18$ & & $\mathrm{RP} \mathrm{b}>\mathrm{S}$ & & $445-51-2,8-10$ & & B & \\
\hline $445-42-3,17-18$ & & $\mathrm{RPb}>\mathrm{S}$ & & $445-51-3,10-12$ & & $\mathrm{R} \mathrm{b}$ & \\
\hline $445-42-4,17-18$ & & $\mathrm{RPb}>\mathrm{S}$ & & $445-51, \mathrm{CC}$ & 483.5 & F P & \\
\hline $445-42-5,31-32$ & & $\mathrm{R}$ b P & & & & & \\
\hline $445-42-6,33-34$ & & B & & & & & \\
\hline \multirow{3}{*}{$445-42, \mathrm{CC}$} & 398.0 & B & & $445-52-1,10-12$ & & $\mathrm{R} \mathrm{b}$ & \\
\hline & & & & $445-52-3,10-12$ & & B & \\
\hline & & & & $445-52, \mathrm{CC}$ & 493 & F P (Nummu- & \\
\hline $\begin{array}{l}445-43-1,91-92 \\
445-43-2,91-92\end{array}$ & & $\mathrm{R} P \mathrm{~b}>\mathrm{S}$ & & & & lites redeposi- & \\
\hline $\begin{array}{l}445-43-2,91-92 \\
445-43-3,91-92\end{array}$ & & $\begin{array}{l}\text { B } \\
\text { B }\end{array}$ & & & & tion) & \\
\hline $445-43-4,91-92$ & & B & & & & & \\
\hline \multirow[t]{2}{*}{$445-43, \mathrm{CC}$} & 407.5 & $\mathrm{R} \mathrm{P} \mathrm{b}$ & & $445-53-1,53-55$ & & R P & $\begin{array}{l}\text { P.21/ } \\
\text { N.2 }\end{array}$ \\
\hline & & & & $445-53-3,53-55$ & & $\mathrm{R} P \mathrm{~b}$ & \\
\hline $445-44-1,119-120$ & & $\mathrm{R}$ b $\mathrm{P}$ & & $445-53-4,68-70$ & & F P (reworked & \\
\hline $445-44-2,119-120$ & & R b P & & & & shallow-water & \\
\hline $445-44-3,119-120$ & & B & & & & Eocene benthic & \\
\hline $445-44-4,119-120$ & & B & & & & faunas) & \\
\hline $445-44, \mathrm{CC}$ & 417.0 & $\mathrm{CMT}$ & & $445-53-5,53-55$ & 502.5 & $\mathrm{~B}(?)$ & \\
\hline $445-45-1,119-120$ & & R b P & & $445-54-1,48-50$ & & B & \\
\hline $445-45-2,119-120$ & & B & & $445-54-3,48-50$ & & B T (?) & \\
\hline $445-45-3,119-120$ & & $\mathrm{RT}$ & & $445-54-5,48-50$ & & B T R (?) & \\
\hline $445-45-4,119-120$ & & R b P & & $445-54, \mathrm{CC}$ & 512 & R P T & \\
\hline $445-45-5,34-35$ & & R b M & & & & & \\
\hline \multirow[t]{2}{*}{$445-45, \mathrm{CC}$} & 426.5 & B & & & & & \\
\hline & & & & $445-55-1,60-62$ & & R P T b & \\
\hline $445-46-1,93-94$ & & & & $445-55-3,60-62$ & & R P T & \\
\hline $445-46-2,93-94$ & & $\mathrm{R}$ b $\mathrm{P}$ & & $445-55-5,60-62$ & & B (?) & \\
\hline $445-46-3,93-94$ & & R P & & $445-55, \mathrm{CC}$ & 521.5 & F P T & \\
\hline $445-46-4,93-94$ & & R P & & & & & \\
\hline $445-46-5,93-94$ & & R P b & & & & $\mathrm{D}$ & \\
\hline $445-46-6,93-94$ & & R P b & & $445-56-1,42-44$ & & $\begin{array}{l}\text { R } \\
\text { P }\end{array}$ & \\
\hline $445-46, \mathrm{CC}$ & 436 & $\begin{array}{l}\text { B } \\
\text { F T }\end{array}$ & & $\begin{array}{l}445-50-5,42-44 \\
445-56-5,42-44\end{array}$ & 531 & B & \\
\hline $445-47-1,50-51$ & & B & & $445-57-1,30-32$ & & R P b & P.18/ \\
\hline $445-47-2,50-51$ & & $\mathrm{R} P>\mathrm{S}$ & & & & & P.17 \\
\hline $445-47-3,50-51$ & & B T (?) & & $445-57-3,80-82$ & & R P b T & \\
\hline $445-47-4,50-51$ & & F T & & $445-57-5,80-82$ & & R P T & \\
\hline $445-47-5,50-51$ & & b P & & $445-57$, CC & 540.5 & F P & \\
\hline $445-47-6,50-51$ & & F T & & & & & \\
\hline \multirow[t]{3}{*}{$445-47, \mathrm{CC}$} & 445.6 & A P T & & & & & \\
\hline & & & & $445-58-1,54-55$ & & R P T P & \\
\hline & & & & $445-58-3,54-55$ & & P T & \\
\hline $445-48-1,100-102$ & & B & & $445-58-5,54-55$ & & R P F T & \\
\hline $445-48-2,100-102$ & & B & & $445-58, \mathrm{CC}$ & 550 & R P & \\
\hline $445-48-3,100-102$ & & B & & & & & \\
\hline $445-48-4,100-102$ & & B & & & & & \\
\hline $445-48-5,100-102$ & & B & & $445-59-1,19-20$ & & R P R P T & \\
\hline \multirow[t]{2}{*}{$445-48, \mathrm{CC}$} & 455 & B & & $445-59-3,19-20$ & & B (?) & \\
\hline & & & & $445-59-5,19-20$ & & R T b & \\
\hline $445-49-1,82-84$ & & B & & $445-59, \mathrm{CC}$ & 559.5 & B & \\
\hline $445-49-2,82-84$ & & $\mathrm{CM} \mathrm{T}$ & $\begin{array}{l}\text { P.22/ } \\
\text { N.3 }\end{array}$ & & & & \\
\hline $445-49-3,82-84$ & & C T & & $445-60-1,67-68$ & & B (?) & \\
\hline $445-49-4,82-84$ & & $\mathrm{~T}(?)$ & & $445-60-3,67-68$ & & B (?) & \\
\hline $445-49-5,82-84$ & & $\mathrm{R} b$ & & $445-60, \mathrm{CC}$ & 569 & R P & \\
\hline \multirow[t]{2}{*}{$445-49, \mathrm{CC}$} & 464.5 & F M T & & & & & \\
\hline & & & & $445-61-1,100-101$ & & $\mathrm{P} \quad \mathrm{T}(?)$ & \\
\hline $445-50-1,48-50$ & & R M T & & $445-61-3,100-101$ & & B T (?) & \\
\hline $445-50-2,48-50$ & & R P T & & $445-61-5,100-101$ & & B & \\
\hline $445-50, \mathrm{CC}$ & 474 & R M T & & $445-61, \mathrm{CC}$ & 578.5 & R P & \\
\hline
\end{tabular}




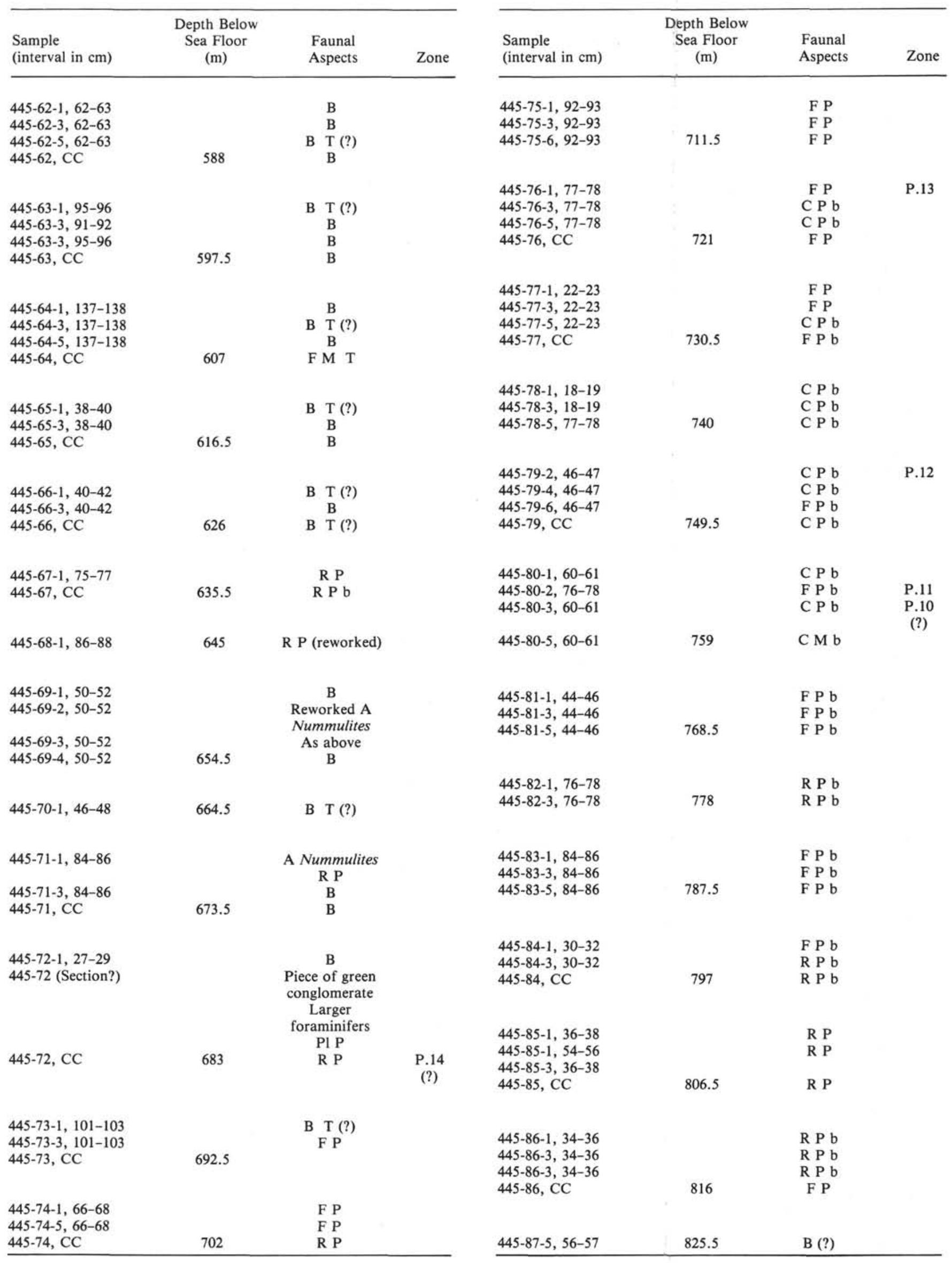




\begin{tabular}{|c|c|c|c|}
\hline $\begin{array}{l}\text { Sample } \\
\text { (interval in cm) }\end{array}$ & $\begin{array}{l}\text { Depth Below } \\
\text { Sea Floor } \\
\text { (m) }\end{array}$ & $\begin{array}{l}\text { Faunal } \\
\text { Aspects }\end{array}$ & Zone \\
\hline $445-88-1,52-54$ & & $\mathrm{R} P \mathrm{~b}$ & \\
\hline $445-88-3,52-54$ & & B & \\
\hline $445-88-5,52-54$ & 835 & $\mathrm{R} P \mathrm{~b}$ & \\
\hline $445-89-2,57-59$ & 844.5 & R P b & \\
\hline $445-90-1,44-46$ & & B & \\
\hline $445-90, \mathrm{CC}$ & 854 & B & \\
\hline $445-91-1,111-112$ & & B & \\
\hline $445-91-5,49-50$ & 863.5 & $\begin{array}{l}\text { Reworked } \\
\text { fragments }\end{array}$ & \\
\hline $445-92-1,59-60$ & & R P (?) & \\
\hline $445-92-3,88-89$ & 873 & R P (?) & \\
\hline \multicolumn{4}{|l|}{$445-93-1,79-80$} \\
\hline $445-93-3,43-44$ & 882.5 & Nummulites & \\
\hline $445-94-1,80-81$ & & B & \\
\hline $445-94-3,130-131$ & 892 & Nummulites? & \\
\hline
\end{tabular}

\section{APPENDIX 5 \\ FORAMINIFERS FROM SITE 446, DAITO BASIN}

Lat. $24^{\circ} 42.04^{\prime} \mathrm{N}$, Long. $132^{\circ} 46.49^{\prime} \mathrm{E}$; Water Depth 4952 meters.

Abundance (specimens per tray), determined at low magnification $(\times 30)$; the following symbols are used:

Abundance

$$
\begin{aligned}
& \mathrm{A}=\text { abundant }=100+ \\
& \mathrm{C}=\text { common }=31-99 \\
& \mathrm{~F}=\text { few } \\
& \mathrm{R}=10-30 \\
& \mathrm{~B}=\text { rare barren }
\end{aligned}
$$

Preservation

\begin{tabular}{|c|c|c|c|}
\hline $\begin{array}{l}\text { Sample } \\
\text { (interval in cm) }\end{array}$ & $\begin{array}{l}\text { Depth Below } \\
\text { Sea Floor } \\
\text { (m) }\end{array}$ & $\begin{array}{l}\text { Faunal } \\
\text { Aspects }\end{array}$ & Zone \\
\hline $446-2-1,55-57$ & & $\mathrm{CP}$ b & $\begin{array}{l}\text { N.19 } \\
(?)\end{array}$ \\
\hline $446-2, \mathrm{CC}$ & 11 & $\mathrm{C} \mathrm{M} \mathrm{b}$ & N.18 \\
\hline $446-3-1,80-82$ & & $\mathrm{FP}$ b & $\begin{array}{c}\text { Mi- } \\
\text { ocene } \\
(?)\end{array}$ \\
\hline $446-3-3,80-82$ & & B & \\
\hline $446-3-5$ & & B & \\
\hline $446-3, \mathrm{CC}$ & 20.5 & B & \\
\hline $446-4, \mathrm{CC}$ & 30 & $\mathrm{RP}$ b $>\mathrm{S}$ & \\
\hline $446-5-3,58-60$ & & B & \\
\hline $446-5-5,58-60$ & & B & \\
\hline $446-5$, CC & 39.5 & B & \\
\hline $446-6-1,60-62$ & & B & \\
\hline $446-6-3,60-62$ & & B & \\
\hline $446-6, \mathrm{CC}$ & 49 & $\mathrm{~B}$ & \\
\hline $446-7-1,56-58$ & & B & \\
\hline $446-7-4,56-58$ & & $\mathrm{~B}$ & \\
\hline $446-7-5,56-58$ & & B & \\
\hline $446-7, \mathrm{CC}$ & 58.5 & B & \\
\hline $446-8-1,70-72$ & & B & \\
\hline $446-8-3,70-72$ & & B & \\
\hline $446-8$, CC & 68 & B & \\
\hline $446-9-1,44-46$ & & B & \\
\hline $446-9-3,44-46$ & & B & \\
\hline $446-9-5,44-46$ & & B & \\
\hline $446-9$, CC & 77.5 & B & \\
\hline $446-10-1,110-112$ & & B & \\
\hline $446-10-3,17-19$ & & B Pl T b (?) & \\
\hline $446-10-5,74-76$ & & B & \\
\hline $446-10$, CC & 87 & B & \\
\hline $446-11-1,67-69$ & & B & \\
\hline $446-11-3,67-69$ & & B & \\
\hline $446-11, \mathrm{CC}$ & 96.5 & B & \\
\hline $446-12-1,39-41$ & & B & \\
\hline $446-12-3,39-41$ & & B & \\
\hline $446-12$, CC & 106 & B & \\
\hline $446-13-1,102-104$ & & B & \\
\hline $446-13-3,105-107$ & & B & \\
\hline $446-13, \mathrm{CC}$ & 115 & B & \\
\hline $446-14-1,110-112$ & & B & \\
\hline $446-14-3,110-112$ & & B & \\
\hline $446-14-5,35-37$ & & A M P b & $\begin{array}{c}\text { P. } 20 / \\
\text { N.1 }\end{array}$ \\
\hline $446-14, \mathrm{CC}$ & 125 & B R T & \\
\hline
\end{tabular}

$$
\begin{aligned}
& \mathrm{G}=\text { good } \\
& \mathrm{M}=\text { moderately good } \\
& \mathrm{P}=\text { poor }
\end{aligned}
$$

Other

$$
\begin{aligned}
& \mathrm{b}=\text { benthic forms } \\
& \mathrm{Pl}=\text { planktonic forms } \\
& \mathrm{T}=\text { tiny foraminifers (juveniles or microforaminifers) } \\
& >\quad=\text { decrease } \\
& \mathrm{S}=\text { size } \\
& \mathrm{D}=\text { diversity }
\end{aligned}
$$

\begin{tabular}{lccc}
\hline $\begin{array}{l}\text { Sample } \\
\text { (interval in cm) }\end{array}$ & $\begin{array}{c}\text { Depth Below } \\
\text { Sea Floor } \\
(\mathrm{m})\end{array}$ & $\begin{array}{c}\text { Faunal } \\
\text { Aspects }\end{array}$ & Zone \\
\hline & & & \\
$446-1-1,71-73$ & 1.5 & B P b & N.21 \\
\hline
\end{tabular}




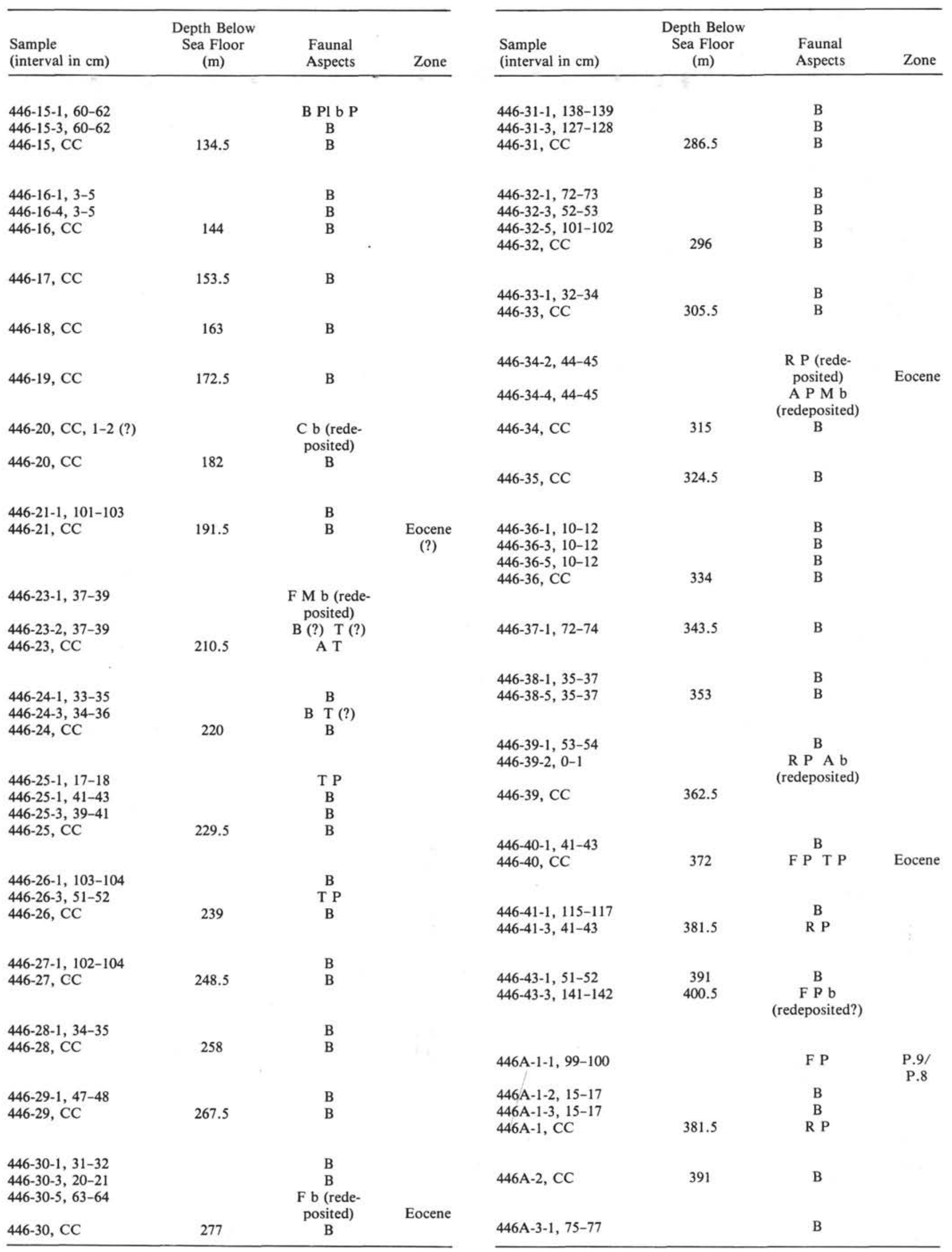




\begin{tabular}{|c|c|c|c|c|c|c|c|}
\hline $\begin{array}{l}\text { Sample } \\
\text { (interval in } \mathrm{cm} \text { ) }\end{array}$ & $\begin{array}{l}\text { Depth Below } \\
\text { Sea Floor } \\
\text { (m) }\end{array}$ & $\begin{array}{l}\text { Faunal } \\
\text { Aspects }\end{array}$ & Zone & $\begin{array}{l}\text { Sample } \\
\text { (interval in } \mathrm{cm} \text { ) }\end{array}$ & $\begin{array}{l}\text { Depth Below } \\
\text { Sea Floor } \\
\text { (m) }\end{array}$ & $\begin{array}{l}\text { Faunal } \\
\text { Aspects }\end{array}$ & Zone \\
\hline $446 \mathrm{~A}-3-2,87-89$ & & B & & $446 \mathrm{~A}-18-1,128-129$ & & R P & \\
\hline $446 \mathrm{~A}-3-3,15-17$ & 400.5 & B & & $446 \mathrm{~A}-18-2,23-25$ & 533.5 & B & \\
\hline $446 \mathrm{~A}-9-1,12-14$ & 448 & B & & $446 \mathrm{~A}-19-3,19-20$ & 543 & B & \\
\hline $\begin{array}{l}446 \mathrm{~A}-10-1,126-128 \\
446 \mathrm{~A}-10-3,140-142 \\
446 \mathrm{~A}-10-5,29-31\end{array}$ & 457.5 & $\begin{array}{l}\text { B } \\
\text { B } \\
\text { B }\end{array}$ & & $446 \mathrm{~A}-22-1,77-78$ & 571.5 & B & \\
\hline & & & & $446 \mathrm{~A}-23-1,62-64$ & 581 & B & \\
\hline $446 \mathrm{~A}-12-3,67-68$ & 476.5 & B & Eocene & & & & \\
\hline $446 \mathrm{~A}-13-3,38-40$ & & $\begin{array}{c}\text { F P b } \\
\text { (redeposited) }\end{array}$ & & $\begin{array}{l}446 \mathrm{~A}-24-1,80-82 \\
446 \mathrm{~A}-24-2,74-75\end{array}$ & 590.5 & $\begin{array}{l}\text { B } \\
\text { B }\end{array}$ & \\
\hline $446 \mathrm{~A}-13, \mathrm{CC}$ & 486 & $\mathrm{R} \mathrm{P} \mathrm{b}$ & & & & & \\
\hline $446 \mathrm{~A}-16-5,40-42$ & 514 & $\begin{array}{c}\text { R P } \\
\text { (redeposited) }\end{array}$ & & $\begin{array}{l}446 \mathrm{~A}-25-3,115-116 \\
446 \mathrm{~A}-25, \mathrm{CC}\end{array}$ & 600 & $\begin{array}{l}\text { B } \\
\text { B }\end{array}$ & \\
\hline $446 \mathrm{~A}-17-1,76-78$ & & B & & $446 \mathrm{~A}-26-3,72-73$ & 609.5 & $\begin{array}{c}\text { R P } \\
\text { (redeposited) }\end{array}$ & \\
\hline $\begin{array}{l}446 A-17-3,53-55 \\
446 A-17, C C\end{array}$ & 524 & $\begin{array}{l}\text { B } \\
\text { B }\end{array}$ & & & & & \\
\hline $446 \mathrm{~A}-18-1,55-57$ & & B & & $\begin{array}{l}446 \mathrm{~A}-28-1,20-21 \\
446 \mathrm{~A}-28, \mathrm{CC}\end{array}$ & 628.5 & $\begin{array}{c}\text { B } \\
\text { R P } \\
\text { (redeposited) }\end{array}$ & \\
\hline
\end{tabular}

